\title{
Ice-sheet configuration in the CMIP5/PMIP3 Last Glacial Maximum experiments
}

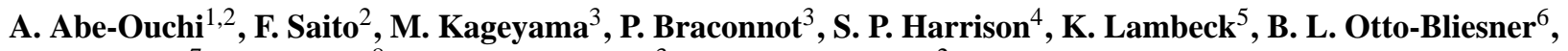 \\ W. R. Peltier ${ }^{7}$, L. Tarasov ${ }^{8}$, J.-Y. Peterschmitt ${ }^{3}$, and K. Takahashi ${ }^{2}$ \\ ${ }^{1}$ Atmosphere Ocean Research Institute, University of Tokyo, 5-1-5, Kashiwanoha, Kashiwa-shi, Chiba 277-8564, Japan \\ ${ }^{2}$ Japan Agency for Marine-Earth Science and Technology, 3173-25 Showamachi, Kanazawa, Yokohama, Kanagawa, \\ 236-0001, Japan \\ ${ }^{3}$ Laboratoire des Sciences du Climat et de l'Environnement/Institut Pierre Simon Laplace unité mixte de recherches \\ CEA-CNRS-UVSQ, Orme des Merisiers, point courrier 129, 91191 Gif sur Yvette Cedex, France \\ ${ }^{4}$ Centre for Past Climate Change and School of Archaeology, Geography and Environmental Sciences, University of Reading, \\ Whiteknights, Reading, RG6 6AH, UK \\ ${ }^{5}$ Research School of Earth Sciences, The Australian National University, Canberra, ACT 0200, Australia \\ ${ }^{6}$ Climate and Global Dynamics Division, National Center for Atmospheric Research, Boulder, CO 80305, USA \\ ${ }^{7}$ Department of Physics, University of Toronto, 60 George Street, Toronto, Ontario, M5S 1A7, Canada \\ ${ }^{8}$ Department of Physics and Physical Oceanography, Memorial University of Newfoundland, St. John's, \\ NL A1B 3X7, Canada
}

Correspondence to: A. Abe-Ouchi (abeouchi@aori.u-tokyo.ac.jp)

Received: 28 April 2015 - Published in Geosci. Model Dev. Discuss.: 3 June 2015

Revised: 25 September 2015 - Accepted: 8 October 2015 - Published: 6 November 2015

\begin{abstract}
We describe the creation of a data set describing changes related to the presence of ice sheets, including ice-sheet extent and height, ice-shelf extent, and the distribution and elevation of ice-free land at the Last Glacial Maximum (LGM), which were used in LGM experiments conducted as part of the fifth phase of the Coupled Modelling Intercomparison Project (CMIP5) and the third phase of the Palaeoclimate Modelling Intercomparison Project (PMIP3). The CMIP5/PMIP3 data sets were created from reconstructions made by three different groups, which were all obtained using a model-inversion approach but differ in the assumptions used in the modelling and in the type of data used as constraints. The ice-sheet extent in the Northern Hemisphere (NH) does not vary substantially between the three individual data sources. The difference in the topography of the $\mathrm{NH}$ ice sheets is also moderate, and smaller than the differences between these reconstructions (and the resultant composite reconstruction) and ice-sheet reconstructions used in previous generations of PMIP. Only two of the individual reconstructions provide information for Antarctica. The discrepancy between these two reconstructions is larger than the dif-
\end{abstract}

ference for the NH ice sheets, although still less than the difference between the composite reconstruction and previous PMIP ice-sheet reconstructions. Although largely confined to the ice-covered regions, differences between the climate response to the individual LGM reconstructions extend over the North Atlantic Ocean and Northern Hemisphere continents, partly through atmospheric stationary waves. Differences between the climate response to the CMIP5/PMIP3 composite and any individual ice-sheet reconstruction are smaller than those between the CMIP5/PMIP3 composite and the ice sheet used in the last phase of PMIP (PMIP2).

\section{Introduction}

There are large differences in the modelled response to scenarios of future climate forcing (Kirtman et al., 2013; Collins et al., 2013). Modelling of past climate states, and evaluation of the simulations using paleoclimate reconstructions, provide unique opportunities to assess the performance of models used for future climate projections when subjected 
to large changes in forcing (Braconnot et al., 2012; MassonDelmotte et al., 2013; Schmidt et al., 2014; Harrison et al., 2015). Palaeo-evaluations are also useful in identifying the causes of inter-model differences in simulated climate responses (Schmidt et al., 2014; Harrison et al., 2015). Thus, the simulation of past climates provides an opportunity to identify and quantify systematic biases that are likely to be present in future climate projections and to explore the potential causes of inter-model spread in these projections. The Last Glacial Maximum (LGM, ca. $21000 \mathrm{yr}$ BP) is an exemplary period for such an exercise because the change in global forcing (relative to the present) was large and, although the forcing was different in nature, similar in magnitude to that expected by the end of the 21st century (Braconnot et al., 2012). The LGM has been a major focus for simulations since the early days of numerical modelling (e.g. Alyea, 1972; Williams et al., 1974; Gates, 1976; Manabe and Hahn, 1977; Kutzbach and Guetter, 1986). It was chosen as a focus for model experiments in both Phase 1 and Phase 2 of the Palaeoclimate Modelling Intercomparison Project (PMIP: Braconnot et al., 2007a, b) because of the availability of syntheses of palaeoclimatic reconstructions (e.g. MARGO Project Members, 2009; Bartlein et al., 2011; Schmittner et al., 2011; Braconnot et al., 2012) for model evaluation. It is perhaps not surprising then that the LGM was one of the simulations chosen when palaeoclimate experiments were first included in the fifth phase of the Coupled Modelling Intercomparison Project (CMIP5: Taylor et al., 2012; Braconnot et al., 2012). The LGM simulations are further examined to constrain the climate sensitivity, which is an important metrics for the future climate projection (Masson-Delmotte et al., 2006, 2013; Hargreaves et al., 2007; Yoshimori et al., 2009, 2011; Brady et al., 2013).

Factors affecting climate that are not simulated explicitly, usually designated boundary conditions, need to be specified in both control and palaeoclimate model simulations. The boundary conditions that must be specified for the LGM experiment are a (relatively small) change in orbital forcing, reduced atmospheric concentrations of greenhouse gases, and the presence of large ice sheets. Land-surface conditions, in particular the distribution of vegetation (Prentice et al., 2000; Harrison and Bartlein, 2012), were also different at the LGM. On the other hand, the spatial coverage of information on LGM vegetation is currently insufficient to provide a gridded global data set to use as a model input. LGM vegetation was therefore either computed by the model or prescribed to be the same as the pre-industrial control simulation. However, the changes in orbital forcing and greenhouse gas concentrations are well known. The expansion of the ice sheets at the LGM resulted in a sea-level lowering of ca. $130 \mathrm{~m}$ and changed palaeogeography. The marginal limits of the North American (Laurentide), Greenland and European ice sheets are increasingly well constrained by radiocarbon-dated moraines and other glacial deposits (e.g. Dyke and Prest, 1987; Mickelson and Colgan, 2003; Dyke,
2004; Gyllencreutz et al., 2007; Simpson et al., 2009; Ehlers et al., 2011; Mangerud et al., 2013). However, there is little direct evidence for the distribution of ice mass, and this must therefore be inferred through a combination of physical modelling and the use of indirect observational constraints (such as information on relative sea-level changes). Thus, the specification of ice-sheet topography has been a major source of uncertainty in defining boundary conditions for LGM experiments.

The earliest LGM simulations made use of a reconstruction of ice-sheet extent and height made by the CLIMAP project (CLIMAP Project Members, 1976; CLIMAP, 1981). Subsequently, the PMIP project made use of reconstructions based on two different generations of an isostatic rebound model: ICE-4G (Peltier, 1994) in the first phase of the project (PMIP1) and ICE-5G v1.1 in PMIP2 (Peltier, 2004). The inferred ice volume was ca. $35 \%$ lower in ICE-4G than in the earlier CLIMAP reconstructions, resulting in considerably lower maximum elevations for the Laurentide and European ice sheets. The Laurentide has a greater volume in ICE-5G than ICE-4G, and the Keewatin Dome is $2-3 \mathrm{~km}$ higher over much of central Canada, but the European ice sheet is less extensive in ICE-5G than ICE-4G.

The lowering of $\mathrm{CO}_{2}$ makes a large contribution to the cooling at the LGM (Broccoli and Manabe, 1987; Hewitt and Mitchell, 1997; Broccoli, 2000; Kim, 2004; Otto-Bliesner et al., 2006; Brady et al., 2013), but the ice sheets (and the changes in albedo caused by the change in land-sea geography associated with the growth of these ice sheets and lowering of sea level) also have an important impact on both regional and global climates, particularly in the NH. Furthermore, the change in ice sheets affects the carbon cycle and atmospheric $\mathrm{CO}_{2}$ concentrations in glacial cycles (Brovkin et al., 2012; Ganopolski and Calov, 2011; Abe-Ouchi et al., 2013). Ice-sheet height has major impacts on surface temperature via lapse rate, planetary-scale atmospheric circulation and the location of storm tracks, and hence precipitation patterns, and even on ocean circulation. Simulations using different ice-sheet configurations have demonstrated these large differences both in global mean temperature and in $\mathrm{NH}$ circulation patterns and regional temperatures (Justino et al., 2005; Otto-Bliesner et al., 2006; Abe-Ouchi et al., 2007; Clark et al., 2009; Pausata et al., 2011; Vettoretti and Peltier, 2013; Ullman et al., 2014; Zhang et al., 2014).

At the time of the definition of the PMIP3 boundary conditions, there were several candidate ice-sheet reconstructions that could have been used as a boundary condition for the CMIP5/PMIP3 LGM simulations (ICE-6G v2.0: Argus and Peltier, 2010; GLAC-1a: Tarasov et al., 2012; ANU: Lambeck et al., 2010), which differ in the assumptions used in the modelling and in the type of data used as constraints on these models. The purpose of this paper is to explain the ice-sheet configuration that was used in the CMIP5/PMIP3 simulations, which was created by blending the three individual realisations, and to explore the consequences of this 
choice. This paper provides the information on the difference between the individual ice sheets and the blended ice sheet as well as ice-sheet configuration of previous phases of PMIP. The individual ice-sheet reconstructions are described in Sect. 2, and the procedure for creating the blended ice sheet is described in Sect. 3. The differences between this blended ice sheet, the individual ice-sheet reconstructions, and previous ice-sheet configurations used by PMIP, and their impact on forcing and climate, are discussed in Sect. 4. The final section of the paper highlights the uncertainties associated with the specification of the CMIP5/PMIP3 ice sheet. It makes recommendations for further work to investigate the impact of ice-sheet configuration on climate change as well as to minimise these uncertainties.

\section{Documentation of the original ice-sheet reconstructions}

\subsection{ICE-6G v2.0 ice reconstruction}

ICE-6G is the latest of a series of inversions of a glacial isostatic adjustment (GIA) model based on the solution for the impulse response of a viscoelastic Earth to surface loading described by Peltier (1974), in which global ice history and radial Earth viscosity profiles are repeatedly tuned to improve model predictions of relative sea-level (RSL) histories and present-day deformation rates compared to observations (Peltier and Andrews, 1976; Tushingham and Peltier, 1991; Peltier, 1976, 1994, 2002, 2004; Argus and Peltier, 2010; Engelhart et al., 2011). The model is based upon detailed and continuously updated analyses of the data of each of the previously glaciated regions (North America: Peltier, 2004; Argus and Peltier, 2010; Fennoscandia: Peltier, 2004; Argus and Peltier, 2010; Greenland: Tarasov and Peltier, 2002, 2004; the British Isles: Peltier, 2002; Shennan et al., 2002; Patagonia: Peltier, 2004; and Antarctica: Peltier, 2004), where each regional analysis is performed in a global context to yield a globally consistent response. In the most recent versions of the model, including the one used as an input to the CMIP5/PMIP3 composite ice sheet, satellite geodetic data (e.g. GPS, GRACE) are used to provide additional constraints (Peltier and Drummond, 2008; Argus and Peltier, 2010). ICE-4G (Peltier, 1994) was used to define the land-sea mask, the ice-sheet extent and elevation, and land-surface topography and palaeo-ocean bathymetry in the first phase of PMIP (PMIP1) and ICE-5G (Peltier, 2004) in the second phase of PMIP (PMIP2). ICE-5G was improved relative to ICE-4G largely through the incorporation of revised information about the extent of the Eurasian ice sheets at the LGM from the QUEEN project (Svendsen et al., 1999; Mangerud et al., 2001, 2002; Svendsen et al., 2004) and the use of gravity changes across North America from the GRACE satellite as an additional constraint.
ICE-6G (or more precisely ICE-6G version 2.0 VM5a T60 Rot) differs from previous inversions through more extensive use of geodetic data as a constraint, including e.g. the Global Positioning Satellite (GPS), satellite laser ranging (SLR), very long baseline interferometry (VLBI), and Doppler Orbitography and Radiopositioning Integrated by Satellite (DORIS). The model uses the VM5a mantle viscosity profile with an elastic lithosphere thickness of $60 \mathrm{~km}$ (T60). VM5a is a three-layer approximation of the VM2 T90 profile described by Peltier and Drummond (2008), in which the lithosphere consists of a $60 \mathrm{~km}$ thick elastic layer above a $40 \mathrm{~km}$ thick layer that is higher viscous. This modification was made to improve the fit of the model to observations of horizontal displacement rates in North America. ICE-6G also takes account of the Earth's rotational effect (Rot) on the geoid. The sea-level predictions from ICE6G have been shown to provide a good fit to several hundred Holocene RSL curves (Argus and Peltier, 2010), including Holocene RSL observations for the Caribbean Sea and the Atlantic coast of North America (Engelhart et al., 2011; Toscano et al., 2011). Engelhart et al. (2011) showed that a further improvement to the match between observations and predictions for the southern part of the Atlantic coast could be obtained by reducing the viscosity on the upper mantle (above $660 \mathrm{~km}$ ) from $0.5 \times 10^{21} \mathrm{~Pa} \mathrm{~s}$ (VM5a) to $0.25 \times 10^{21} \mathrm{~Pa}$ s (VM5b). However, subsequent work (Roy and Peltier, 2015) has shown that an even better match is obtained by reducing the viscosity of the upper part of the lower mantle.

\subsection{GLAC-1a ice reconstruction}

The GLAC-1a reconstruction is based on a set of glaciological models that are derived from a plausible climate forcing based on PMIP1 and PMIP2 results for LGM and that fit independently derived ice margin chronologies, within explicit uncertainties. The climate forcing involves an interpolation between present-day observed climatologies and the set of highest-resolution LGM fields from PMIP1 and PMIP2 data sets. The interpolation is weighted according to a glaciological inversion of the GRIP record (Tarasov and Peltier, 2003) for regional temperatures over the last glacial cycle.

The North American and Eurasian reconstructions are derived from separate Bayesian calibrations of the Glacial Systems Model (GSM). The GSM incorporates a 3-D thermomechanically coupled ice-sheet model based on the shallow ice approximation, a permafrost resolving bed thermal model, an asynchronously coupled down-slope surface drainage/lake depth solver, and also includes thermodynamic lake ice, sub-glacial till deformation, buoyancy and temperature-dependent ice calving, and an ice-shelf representation (Tarasov and Peltier, 2004, 2005, 2007; Tarasov et al., 2012). The visco-elastic bedrock response uses either the VM2 (as used in ICE-5G) or VM5a (used in ICE-6G) earth rheologies. RSL is computed using a gravitationally 
self-consistent formalism similar to that of Peltier (2009), except that it includes an eustatic approximation for dealing with changing ocean masks and does not take account of Earth rotational effects (Tarasov et al., 2012).

Separate calibrations are made for North America and Eurasia. The calibration involves 36 ensemble parameters for North America and 29 ensemble parameters for Eurasia, to capture uncertainties in deglacial climate and ice dynamics. The majority of these parameters are used for the climate forcing, including weighting the empirical orthogonal functions (EOFs) between PMIP models for LGM monthly precipitation and temperature, regional desert elevation effects, and LGM atmospheric lapse rate. Other ensemble parameters adjust the calving response, the effective viscosity of subglacial till, the strength of the ice-marginal constraint, and flow parameters for ice shelves. Model runs are forced to stay within uncertainties of independently derived ice margin chronologies for North America (Dyke, 2004) and Eurasia (Hughes et al., 2014). Calibration targets include RSL observations from 512 sites (Tarasov and Peltier, 2002), geologically inferred deglacial ice-margin chronologies, and geodetic constraints from Argus and Peltier (2010). In the case of North America, the calibrated ensemble is further scored with respect to strand lines (paleo lake-level indicators) and observations of the maximum level of marine inundation. Model runs are penalised in proportion to the amount of margin correction (or "margin forcing"; see Sect. 2.4 of Tarasov and Peltier, 2004) required, so the calibration is directed towards a climate forcing that is consistent with the margin chronology.

The model was originally calibrated using the ICE-4G ice load reconstruction for Antarctica and the VM2 Earth rheology. However, the subsequent use of an expanded geodetic data set for North America coupled with the significant reduction in LGM Antarctic ice volume in ICE-6G v. 2 compared to ICE-4G led to a significant misfit with the far-field Barbados RSL record. A random 2000 member ensemble was generated along with a rerun of the best 300 previously calibrated parameter sets and some 200 attempts at handtuning. There is a significant tradeoff between fitting the Barbados constraint and fitting the constraints from other locations. In order to satisfy the Barbados constraint, the 1.5 sigma upper limit of the previously calibrated ensemble for North America (which almost reaches the inferred Barbados record for 26 to $21 \mathrm{ka}$ ) was used. A weighted ensemble mean of the model runs that passed hard threshold constraints in the previous calibration was used for North America. The Eurasian calibration converged and was successful, except for minor issues with the Norwegian fjords. A single run with the largest $26 \mathrm{ka}$ RSL contribution to the Barbados record was therefore used. A single run was chosen to ensure consistency between drainage fields and the surface topography. The Greenland model is from Tarasov and Peltier (2002, 2003), a glaciological model with hand-tuned climate adjust- ments to enforce fit to RSL records and the GRIP borehole temperature record.

\subsection{ANU ice reconstruction}

The ANU reconstruction has also evolved over a period of years in an iterative fashion (Lambeck and Johnston, 1998; Lambeck and Chappell, 2001; Lambeck et al., 2014). The first iterations were based on the analysis of far-field sealevel data, where the sea-level signal is predominantly a measure of the changes in total ice volume (the ice-volume equivalent sea level or ESL). The principle isostatic contribution to these sea levels is from the change in water load, a function of the rate at which water is added into or removed from the oceans and how it is distributed within ocean basins. Simple models were initially used for the ice sheets. The separation of mantle rheology from the ESL function was achieved by using the spatial variability of the far-field sea-level signals (Nakada and Lambeck, 1989). The resulting ice volume was then redistributed between the ice sheets using scaling relations initially and iterating between far-field and nearfield solutions to ensure convergence (Lambeck et al., 2002, 2014).

Inversions were also made for individual $\mathrm{NH}$ ice sheets using new compilations of field data from within and close to the ice margins, which are sensitive to the ice model and mantle rheology. Separate reconstructions have been made for Scandinavia (Lambeck et al., 1998, 2010), the BarentsKara region (Lambeck, 1995a, 1996), Greenland (Fleming and Lambeck, 2004), the British Isles (Lambeck, 1993, 1995b), and North America (Lambeck, Purcell and Zhao, unpublished). These separate solutions allow lateral variability in mantle viscosity beneath the individual ice sheets to be detected, as well as differences between oceanic and continental mantles (Lambeck and Chappell, 2001). Some interactions occur between the separate ice-sheet solutions, requiring further iterations as each ice-sheet model is modified.

The field data from Antarctica are insufficient to use a similar approach to reconstruct ice-volume changes. Volume changes for the Antarctic ESL were obtained as the difference between the global ESL (Lambeck et al., 2014) and the NH ESL, the latter being the sum of the individual icesheet contributions, and including mountain deglaciation in both hemispheres (Lambeck and Purcell, 2005). The ice in Antarctica was then distributed using the LGM ice margins proposed by Anderson et al. (2002), and assuming the ice profiles followed the quasi-parabolic function proposed by Paterson (1994). The retreat history is determined by the difference between the global ESL function and the combined Northern Hemisphere mountain-glacier contributions. This reconstruction is not meant to be an accurate reflection of Antarctic ice history. Rather it is a convenient way of disposing of ice volume that cannot be attributed to the $\mathrm{NH}$ ice sheets in a way that does not impact in a major way on the far-field and $\mathrm{NH}$ analyses. 
Several iterations have been performed to combine the far-field and individual ice-sheet reconstructions. The results used to create the CMIP5/PMIP3 composite are based on solutions current in 2009. The inversions yield changes in ice thickness compared to the present-day volume of each ice sheet. Thus, the LGM ice thickness is obtained by adding the present-day ice thickness. The LGM ice elevation with respect to sea level at the LGM is obtained by subtracting the sea-level change (geoid change beneath the ice sheet) from the LGM ice thickness. The ESL function used in these solutions is defined as all land ice and grounded ice on the shelves. The LGM ocean margin is defined by the icegrounding line (Lambeck et al., 2003).

\section{Construction of the composite CMIP5/PMIP3 ice sheets}

\subsection{Terminology}

We use the term "topography" to refer to the elevation of the upper ice surface if the land is covered by ice, including floating ice, or the elevation of the land surface or ocean floor in areas not covered by ice or floating ice. Topography can be expressed either relative to modern sea level or relative to the sea level at a specific time $t$. We use $\operatorname{Topo}(t)$ for topography relative to the sea level at time $t$, and topo $(t)$ for topography expressed relative to the modern sea level (i.e. when $t$ is 0 ).

Surface elevation (Surf) is the elevation of the bottom of the atmosphere. $\operatorname{Surf}(t)$ is defined as

$\operatorname{Surf}(t)=\max [0, \operatorname{Topo}(t)]$,

which is 0 for ocean grid points and topography otherwise. Bathymetry (Bath) is the elevation of the ocean floor under ice shelves or topography otherwise.

There are four components that need to be provided to define ice-sheet-related boundary conditions at the LGM: the difference in surface elevation ( $\Delta$ Surf), an ice mask (Mask ${ }_{1}$ ), an ice-shelf mask (Mask 2 ) and a land-sea mask $\left(\right.$ Mask $\left._{3}\right)$. The first term ( $\Delta$ Surf) is the difference in the surface elevation between LGM and the present day. The three masks define the conditions at individual grid points. In the ice mask (Mask 1 ), 0 indicates ice-free and 1 indicates ice-covered grid points, including floating ice points. In the ice-shelf mask (Mask 2 ), 0 indicates ice-free points, 1 indicates grounded ice, and 2 indicates floating-ice grid points. In the land-sea mask (Mask 3 ), 0 indicates land and 1 indicates ocean grid points. This information is provided for the domain from -180 to $179^{\circ}$ in longitude and -89.5 to $89.5^{\circ}$ in latitude, at a spatial resolution of $1^{\circ} \times 1^{\circ}$.

\subsection{Conversion to common grid}

The difference in the surface elevation at the LGM can be computed as

$\Delta \operatorname{Surf}(21 \mathrm{ka})=\operatorname{Surf}(21 \mathrm{ka})-\operatorname{Surf}(0 \mathrm{ka})$.

However, each of the individual ice-sheet reconstructions provides different outputs corresponding to the terms on the right-hand side of this equation (Table 1). ANU provides estimates of the change in thickness between the LGM and the present day ( $\Delta$ Thick) and relative sea level (RSL), GLAC1a provides Thick and topo $(21 \mathrm{ka})$, while ICE-6G provides Topo $(21 \mathrm{ka})$ and bathymetry Bath $(21 \mathrm{ka})$ as well as providing explicit masks for 21 and $0 \mathrm{ka}$. In order to produce the composite CMIP5/PMIP3 data set, it was therefore necessary to transform the original outputs before interpolating these data onto a common grid.

The domain of ICE-6G v2.0 is the same as that used in the composite CMIP5/PMIP3 reconstructions, so no spatial transformation was needed. The difference in the surface elevation at the LGM compared to the present day was computed from the original variables as

$$
\begin{aligned}
\Delta \operatorname{Surf}(21 \mathrm{ka}) & =\max [0, \operatorname{Topo}(21 \mathrm{ka})] \\
& -\max [0, \operatorname{Topo}(0 \mathrm{ka})] .
\end{aligned}
$$

The ice mask, Mask 1 (21 ka), was extracted directly from the original reconstruction. The ice-shelf mask, Mask $_{2}(21 \mathrm{ka})$, was computed from Topo and Bath as

$\operatorname{Mask}_{2}(21 \mathrm{ka})= \begin{cases}2 & \text { if Topo } \neq \text { Bath } \\ \operatorname{Mask}_{1} & \text { otherwise }\end{cases}$

The ANU reconstruction provides RSL and ( $\Delta$ Thick) for four separate regions (Table 1). RSL over the British Isles was computed under the assumption that the present day is in equilibrium, with a mantle density of $4500 \mathrm{~kg} \mathrm{~m}^{-3}$. These terms were first interpolated to the PMIP3 spatial grid, but no attempt was made to attribute values to grid points beyond those covered by the original data set.

The LGM topography was computed as

$\operatorname{Topo}(21 \mathrm{ka})=\operatorname{Topo}(0 \mathrm{ka})+\Delta$ Thick $-\mathrm{RSL}$,

where Topo $(0 \mathrm{ka})$ was derived from the ETOPO1 data set (Amante and Eakins, 2009). Ice-covered grid points that were still under $0 \mathrm{~m}$ (i.e. sea-level elevation) after this procedure were corrected using an ice-floating adjustment, using ice and water densities of 910 and $1028 \mathrm{~kg} \mathrm{~m}^{-3}$ respectively. Topography was then converted to $\Delta$ Surf using Eq. (3). There are several grid cells (e.g. near ice divides) where ice is present but $\Delta$ Thick $=0$. A modern reference ice mask is therefore required to compute the LGM ice mask for the ANU reconstruction. The LGM ice mask was therefore com- 
Table 1. The spatial domain and output variables provided by each of the individual ice-sheet reconstructions, ICE-6G v.2, GLAC-1a and ANU. Latitude and longitude ranges are expressed in decimal degrees, where positive indicates north and east respectively and negative indicates south and west.

\begin{tabular}{|c|c|c|c|c|c|}
\hline Reconstruction & Region & Latitude $\left({ }^{\circ}\right)$ & Longitude $\left(^{\circ}\right)$ & Resolution $\left({ }^{\circ}\right)$ & Variables provided \\
\hline ICE-6G v.2 & Global & {$[-89.5,89.5]$} & {$[0,359]$} & $1 \times 1$ & $\begin{array}{l}\operatorname{Mask}(21 \mathrm{ka}), \operatorname{Topo}(21 \mathrm{ka}), \\
\text { Bath(21 ka), Mask(0ka), } \\
\text { Topo(0ka), Bath(0ka) }\end{array}$ \\
\hline GLAC-1a & $\begin{array}{l}\text { North America } \\
\text { Eurasia }\end{array}$ & $\begin{array}{l}{[34.75,84.25]} \\
{[48.125,83.125]}\end{array}$ & $\begin{array}{l}{[187.5,354.5]} \\
{[-12.75,119.25]}\end{array}$ & $\begin{array}{l}1 \times 0.5 \\
0.5 \times 0.25\end{array}$ & Thick(21 ka), topo(21 ka) \\
\hline ANU & $\begin{array}{l}\text { Antarctica } \\
\text { Eurasia } \\
\text { North America }\end{array}$ & $\begin{array}{l}{[-89.5,-61.5]} \\
{[50.25,83]} \\
{[38,84.5]}\end{array}$ & $\begin{array}{l}{[-179,180]} \\
{[0,115.5]} \\
{[-139,-7]}\end{array}$ & $\begin{array}{l}1 \times 1 \\
0.5 \times 0.25 \\
0.5 \times 0.25\end{array}$ & $\Delta$ Thick $(21 \mathrm{ka}), \operatorname{RSL}(21 \mathrm{ka})$ \\
\hline & Britain & {$[52,59]$} & {$[-10,4]$} & $1 \times 1$ & $\Delta$ Thick(20ka) \\
\hline
\end{tabular}

puted as

$\operatorname{Mask}_{1}(21 \mathrm{ka})= \begin{cases}0 & \text { if Topo } \neq \text { Bath } \\ 1 & \text { else if ICE-6GMask } 1=1 \\ 1 & \text { else if } \Delta \text { Thick }(21 \mathrm{ka})>0 \\ 0 & \text { otherwise }\end{cases}$

The ice-shelf mask was computed as

$\operatorname{Mask}_{2}= \begin{cases}2 & \text { if } \operatorname{Topo}(21 \mathrm{ka})<0 \\ 1 & \text { if } \operatorname{Mask}_{1}=1 \\ 0 & \text { otherwise }\end{cases}$

The GLAC-1a reconstruction provides Thick $(21 \mathrm{ka})$ and topo(21 ka) for North America and Eurasia, and specifies the global sea-level change of $116 \mathrm{~m}$. The topography relative to the LGM sea level is computed as

$\operatorname{Topo}(21 \mathrm{ka})=\operatorname{topo}(21 \mathrm{ka})+116 \mathrm{~m}$.

The resulting values were then interpolated to the PMIP3 grid, although no attempt was made to attribute values to grid points beyond those covered by the original data set (i.e. Antarctica). Grid points that were ice-covered but below sea level were corrected using the same floating-ice adjustment as used for the ANU reconstruction. $\triangle$ Surf was then computed using Eq. (3). The ice mask was computed from $\operatorname{Thick}(21 \mathrm{ka})$ as

$\operatorname{Mask}_{1}= \begin{cases}0 & \text { if } \operatorname{Thick}(21 \mathrm{ka})=0 \\ 1 & \text { otherwise }\end{cases}$

The ice-shelf mask was computed using Eq. (7).

\subsection{Integration of the three reconstructions}

The CMIP5/PMIP3 composite ice-sheet reconstruction was created from the three transformed individual reconstructions. The LGM ice mask was taken as the maximum pos- sible coverage:

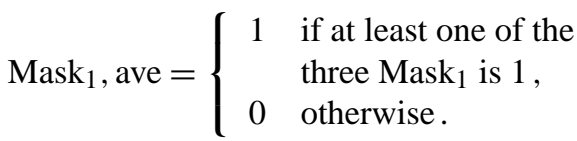

The surface elevation for ice-free grid cells was taken from ICE-6G v.2, while the difference in the surface elevation for ice-covered grid cells was computed by averaging the three reconstructions:

$\Delta$ Surf $=\left\{\begin{array}{c}\left(\Delta \text { Surf }^{\prime}(\text { ANU })+\Delta \text { Surf }^{\prime}(\text { ICE-6G })\right. \\ \left.+\Delta \text { Surf }^{\prime}(\text { GLAC-1 })\right) / N_{\mathrm{d}} \\ \quad \text { where Mask } 1, \text { ave }=1, \\ \Delta \text { Surf }(\text { ICE-6G }) \text { otherwise },\end{array}\right.$

where $N_{\mathrm{d}}$ is the number of individual data sets (i.e. between 1 and 3) which provide a value for $\Delta$ Surf for a given grid point, and $\Delta$ Surf $^{\prime}$ is the surface elevation field extended over undefined grid points such that

$\Delta \operatorname{Surf}^{\prime}= \begin{cases}\Delta \text { Surf } & \text { if defined } \\ 0 & \text { if undefined (no quantity) } .\end{cases}$

The ice-shelf mask is computed as the minimum possible shelf coverage.

Mask $_{2, \text { ave }}= \begin{cases}1 & \begin{array}{l}\text { if at least one of the three } \\ \text { Mask } 2 \text { is } 1,\end{array} \\ 0 & \text { if all of the three } \text { Mask }_{2} \text { are } 0, \\ 2 & \text { otherwise. }\end{cases}$

The resulting mask had five glaciated grid points where $\Delta$ Surf was anomalously much lower than the surrounding points. We took the average value of the surrounding grid points, in order to avoid unrealistic spatial variability in icesheet topography. The present-day area of the Caspian Sea was included in the LGM land-sea mask, and a small number of land grid cells spuriously assigned to the ocean were also corrected. 
Table 2. Implied changes (Last Glacial Maximum-present) in ice volume for the Laurentide, Eurasian and Antarctic ice sheets, expressed in terms of impact on eustatic sea level (in $\mathrm{m}$ ). The impact of eustatic sea level is inferred by assuming no change in ocean area compared to today (assumed ocean area: $360768576 \mathrm{~km}^{2}$ ), and using densities for ice and water of 910 and $1028 \mathrm{~kg} \mathrm{~m}^{-3}$ respectively. Results are shown for the three individual reconstructions (ICE-6G v.2, GLAC-1a, ANU) and for the composite CMIP5/PMIP3 ice sheets, and compared to the implied changes for the ice sheets used in the Last Glacial Maximum simulations run in the first and second phases of the Palaeoclimate Modelling Intercomparison Project (PMIP1, PMIP2).

\begin{tabular}{lllll}
\hline & North America & Eurasia & Antarctica & Total \\
\hline ICE-6Gv.2 & 76.8 & 17.5 & 15.6 & 113.0 \\
GLAC-1a & 76.6 & 14.0 & Not reconstructed & Not available \\
ANU & 82.5 & 18.2 & 29.0 & 130.0 \\
CMIP5/PMIP3 composite & 78.6 & 16.6 & 22.3 & 121.5 \\
PMIP1(ICE-4G) & 60.5 & 29.1 & 21.7 & 117.8 \\
PMIP2(ICE-5Gv1.1) & 74.6 & 20.3 & 17.3 & 112.2 \\
\hline
\end{tabular}

\section{Comparison of the ice-sheet reconstructions}

\subsection{Comparison of the individual ice-sheet reconstructions}

The ANU reconstruction shows larger changes in all of the individual ice sheets than shown by either the GLAC-1a or the ICE-6G v.2 reconstruction, while the GLAC-1a reconstruction shows smaller changes in $\mathrm{NH}$ ice-sheet volume than the other two reconstructions (Table 2). The estimates for the Laurentide Ice Sheet, when expressed in terms of eustatic sea level, vary from 83 to $77 \mathrm{~m}$, and the estimates for the Eurasian ice sheet from 18 to $14 \mathrm{~m}$. The GLAC-1a reconstruction shows the Laurentide Ice Sheet as a single broad dome, with maximum elevations $(<3000 \mathrm{~m})$ in the west (Fig. 1). ICE-6G v.2 also shows maximum elevations in the western part of the ice sheet, but has a smaller secondary maximum over the James Bay area (Fig. 1). A larger part of the Laurentide Ice Sheet has elevations $>3000 \mathrm{~m}$ in the ANU reconstruction (Fig. 1). The GLAC-1a and ICE-6G v.2 reconstructions for Greenland are similar (because they are essentially derived from the same model: see Tarasov and Peltier, 2002,2004 ) and show a flatter ice sheet with increased elevations around the margin and somewhat lower elevations than today in the centre (Fig. 2). The ANU reconstruction does not show lower central elevations, but does have an increase in marginal elevations. All three reconstructions show the Eurasian ice sheet with two major domes, one centred upon the Gulf of Bothnia and the other over the Barents Sea. The ANU reconstruction has elevations $>3000 \mathrm{~m}$ for the western dome, whereas both domes are of similar and lower (2000$3000 \mathrm{~m}$ ) elevation in the ICE-6G v.2 and GLAC-1a reconstructions (Figs. 1, 2).

Only ICE-6G v.2 and ANU provide independent reconstructions of Antarctica. The volumetric change, when expressed in terms of eustatic sea level, is nearly twice as large in the ANU reconstruction $(29 \mathrm{~m})$ than in the ICE-6G v.2 reconstruction $(15.6 \mathrm{~m})$ (Table 2). More of the eastern part of the ice sheet lies at elevations $>3000 \mathrm{~m}$ in the ANU re-

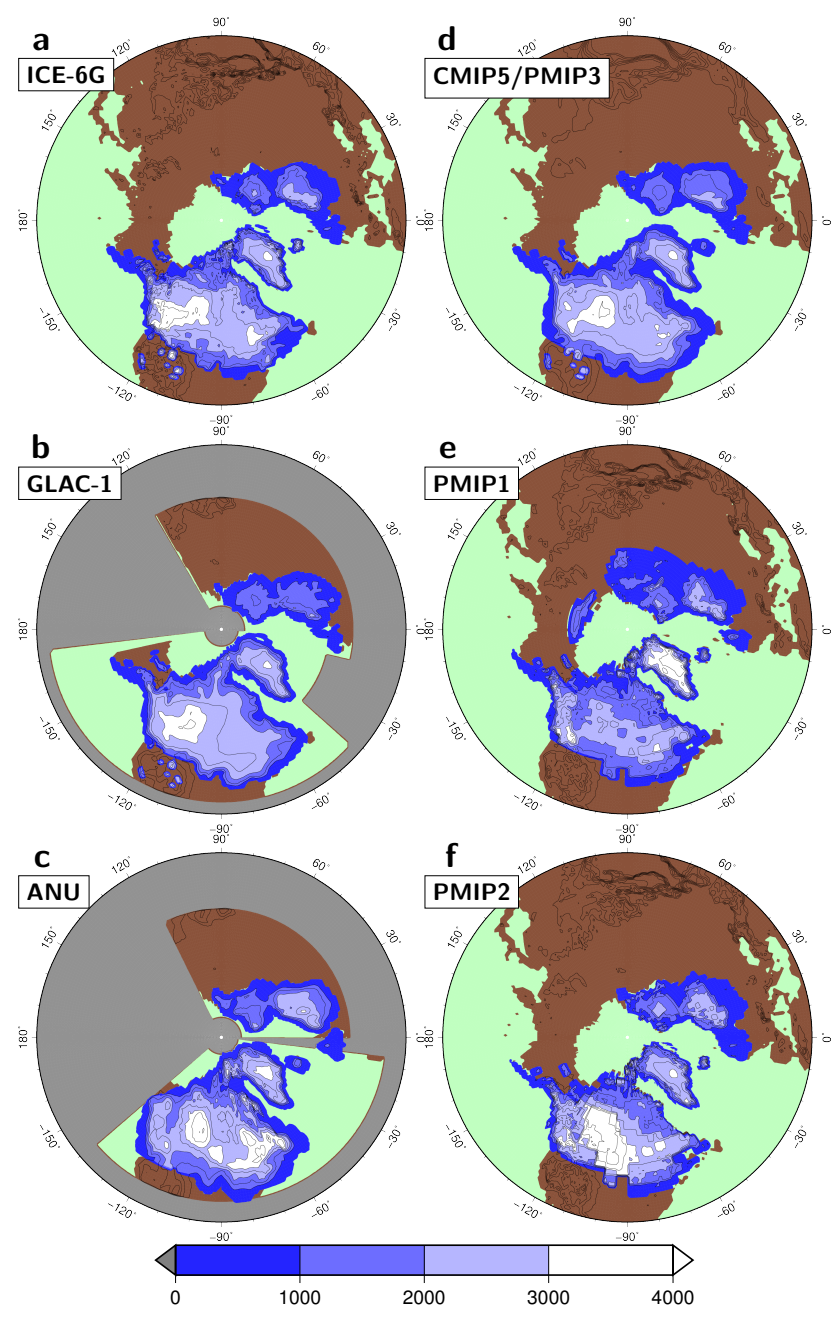

Figure 1. Surface elevation $(\mathrm{m})$ at the Last Glacial Maximum (LGM) Northern Hemisphere ice sheets from the (a) ICE-6G v.2, (b) GLAC-1a and (c) ANU reconstructions, and for the (d) CMIP5/PMIP3 composite compared to the ice sheets used in (e) PMIP1 and (f) PMIP2. 

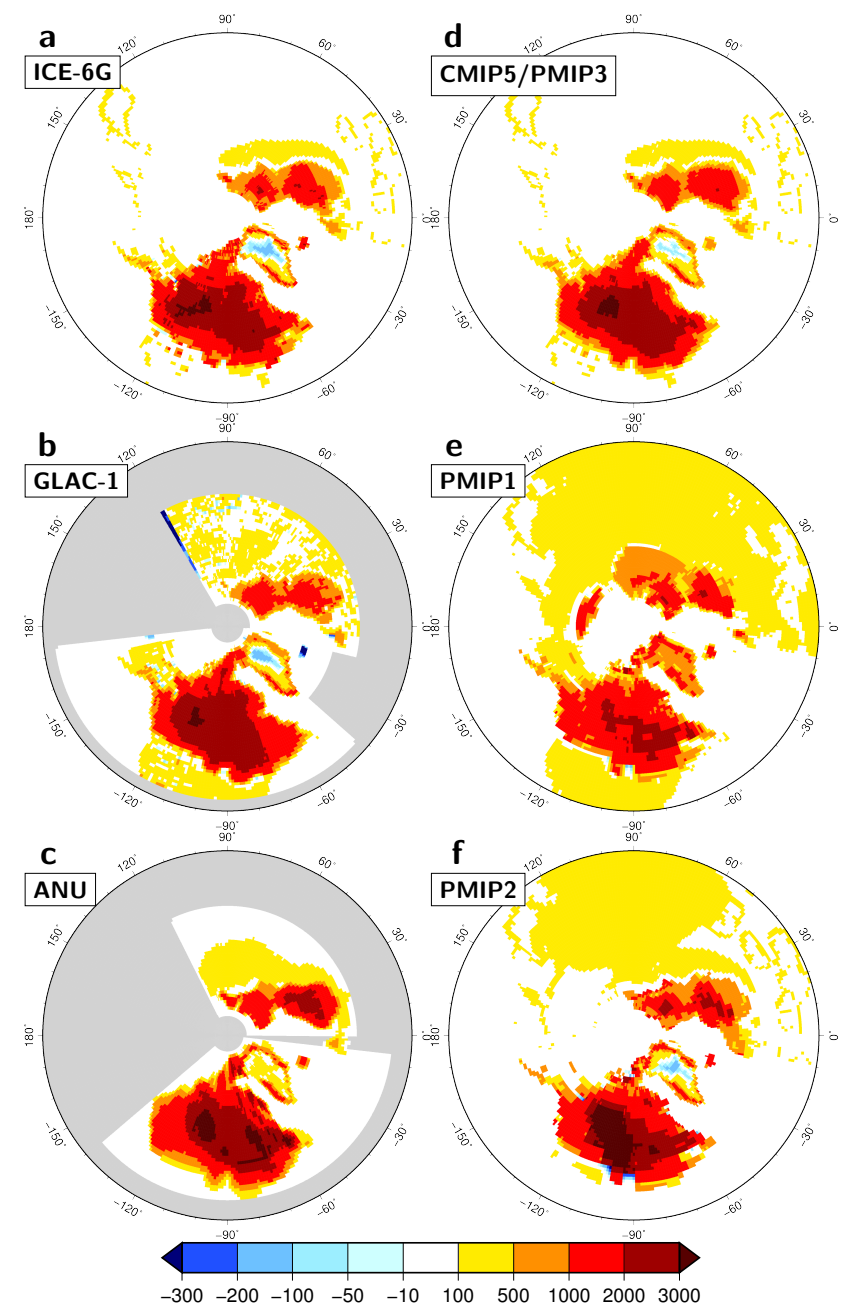

Figure 2. Difference in surface elevation $(\mathrm{m})$ of the Northern Hemisphere ice sheets at the LGM compared to the present day from the (a) ICE-6Gv.2, (b) GLAC-1a and (c) ANU reconstructions, and for the (d) CMIP5/PMIP3 composite compared to the ice sheets used in (e) PMIP1 and (f) PMIP2. The region shown is between 40 and $90^{\circ} \mathrm{N}$.

construction (Fig. 3), whereas the ICE-6G v. 2 reconstruction has a secondary dome at elevations $>3000 \mathrm{~m}$ over the Marie Byrd region, which is not present in the ANU reconstructions. In both reconstructions, the major differences in elevation between the LGM and present are in western Antarctica, where elevation is higher by ca. $900 \mathrm{~m}$ at the LGM than today (Fig. 4). The area of increased elevation is larger in the ANU reconstruction than in the ICE-6G v. 2 reconstruction.

Although all of the individual reconstructions are constructed using information on the location of the margins of each ice sheet, nevertheless the final reconstructed extent of the ice sheets is derived from the inverse model. Thus, there may be discrepancies between the reconstructions and the actual, observed location of the LGM margins of each ice sheet. There are indeed differences between the ice and ice-

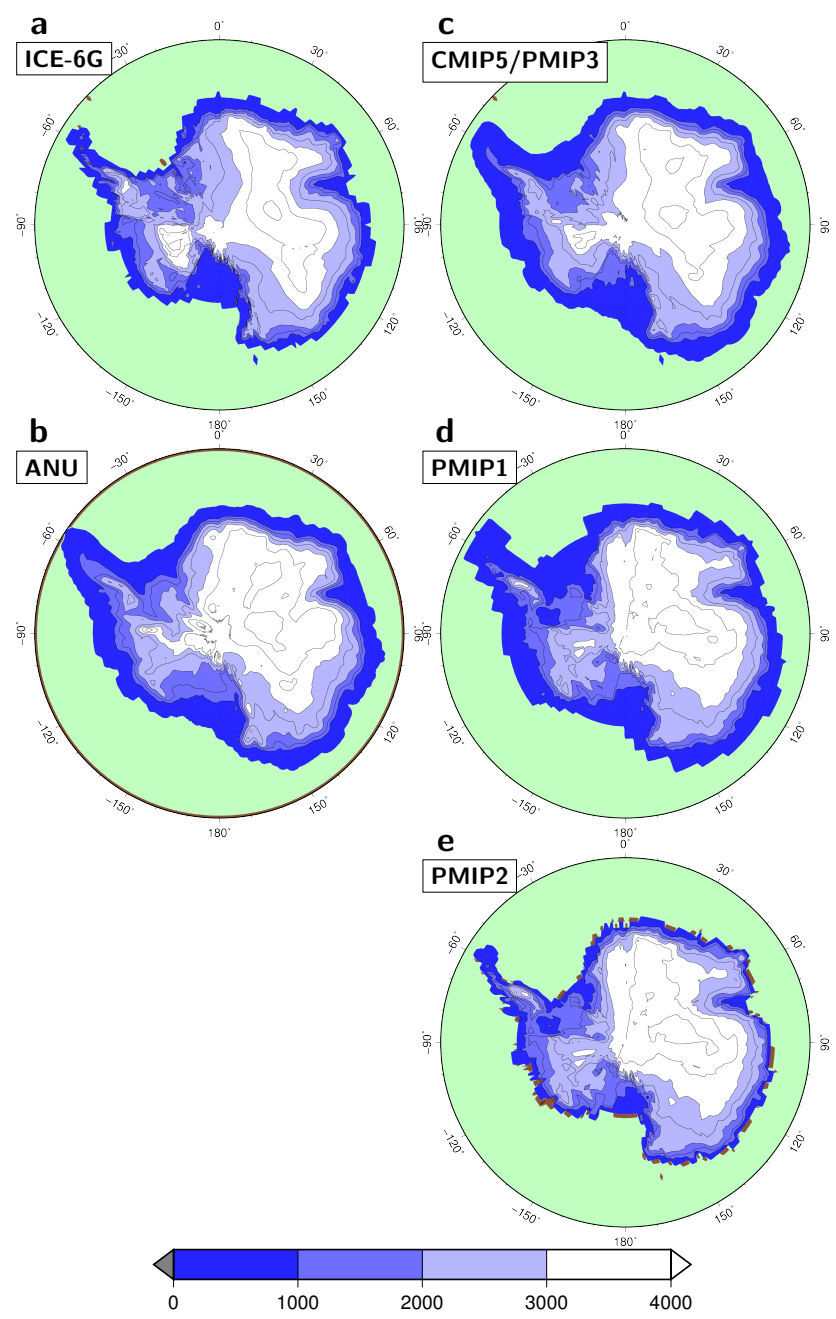

Figure 3. Surface elevation (m) of Antarctica at the LGM from the (a) ICE-6G v.2, (b) ANU reconstructions, and for (c) the CMIP5/PMIP3 composite compared to the ice sheets used in (d) PMIP1 and (e) PMIP2. The GLAC-1a reconstruction for Antarctica is identical to that of ICE-6G, and is therefore not shown.

shelf and land-sea masks obtained from each of the individual reconstructions. The implied change in eustatic sea level (Table 2) is larger in the ANU reconstruction than in the ICE$6 \mathrm{G}$ v. 2 reconstruction. Similarly, the extent of ice shelves is consistently smaller in the ICE-6G v. 2 reconstruction than in the ANU reconstruction, both for the $\mathrm{NH}$ and around Antarctica (Fig. 5).

\subsection{Comparison of the CMIP5/PMIP3 composite reconstruction with earlier PMIP ice sheets}

Ice-sheet reconstructions used in the first two phases of PMIP were based on earlier versions of the ICE-6G inversion approach: ICE-4G (Peltier, 1994) for the first phase of PMIP (PMIP1) and ICE-5G (Peltier, 2004) for the second phase of PMIP (PMIP2). ICE-5G was improved relative to ICE- 


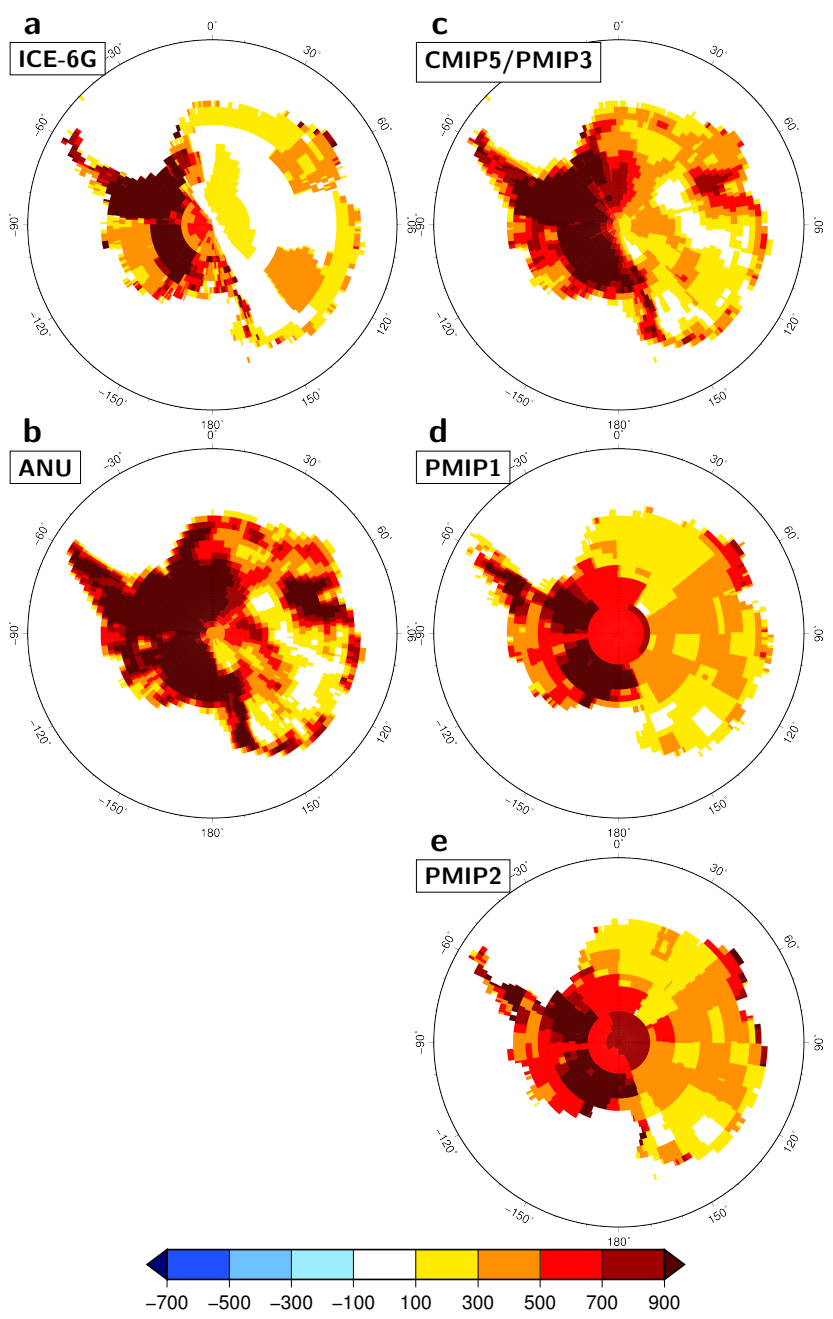

Figure 4. Difference in surface elevation (m) of Antarctica at the LGM compared to the present day from the (a) ICE-6Gv.2, (b) ANU reconstructions, and for (c) the CMIP5/PMIP3 composite compared to the ice sheets used in (d) PMIP1 and (e) PMIP2. The GLAC-1a reconstruction for Antarctica is identical to that of ICE-6G, and is therefore not shown.

4G through the incorporation of revised information about the extent of the Eurasian ice sheets at the LGM from the QUEEN project (Svendsen et al., 1999; Mangerud et al., 2001, 2002; Svendsen et al., 2004). ICE-6G differs from ICE-5G because of the inclusion of constraints based on satellite geodetic data as well as a more extensive data set of relative sea-level changes. The differences between the three reconstructions are substantial. The PMIP2 NH ice sheets are considerably higher than the CMIP5/PMIP3 composite ice sheet, while the PMIP1 NH ice sheets are lower than the CMIP5/PMIP3 composite and do not show the pronounced dome in the western part of the Laurentide (Figs. 1,2). The Eurasian ice sheet is less extensive in the CMIP5/PMIP3 composite reconstruction than in the earlier reconstructions and maximum elevations are lower than in the earlier PMIP
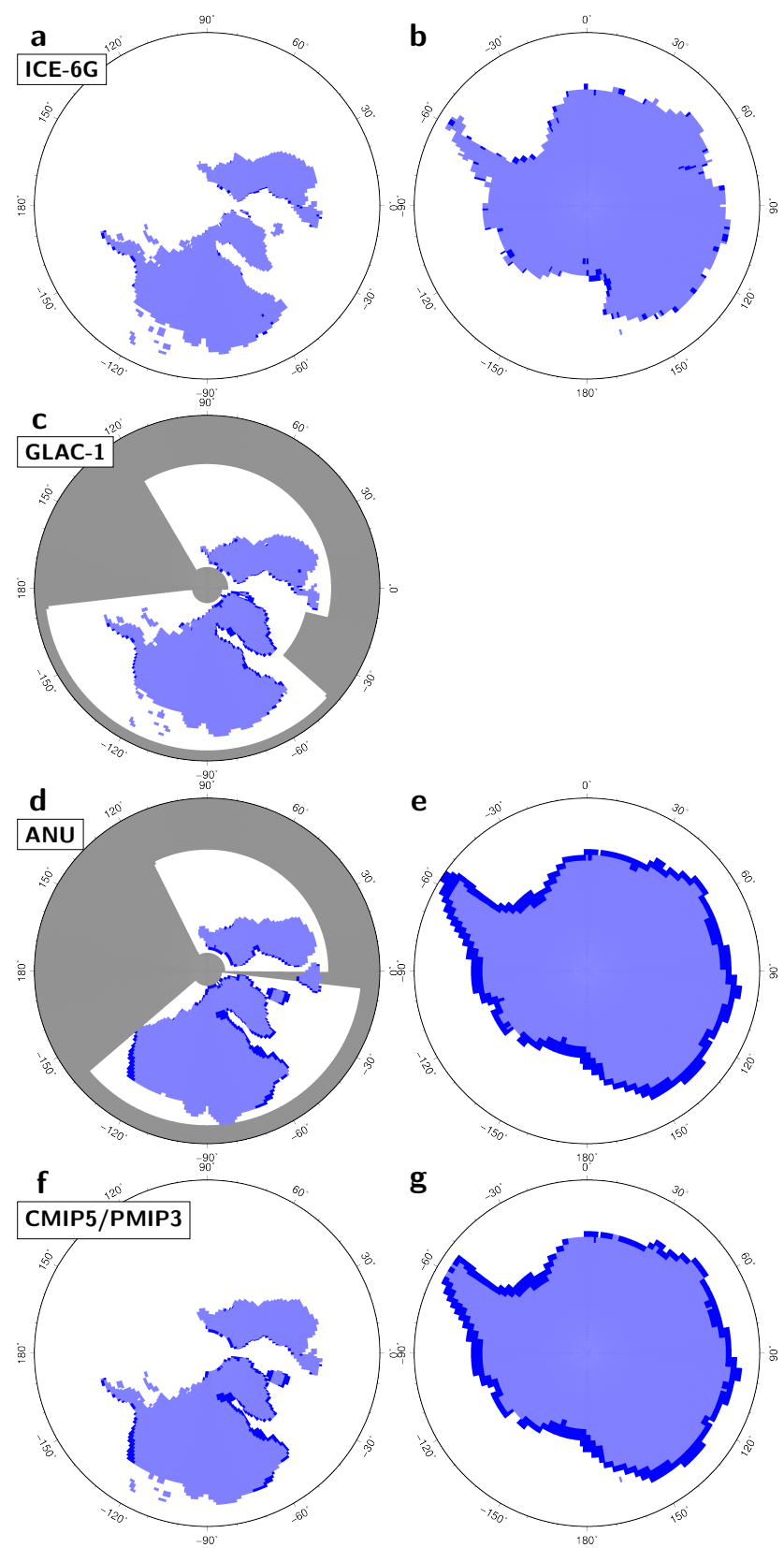

Figure 5. Ice-shelf extent at the LGM from the ice-shelf masks for the Northern Hemisphere derived from ICE-6G v. 2 for (a) the Northern Hemisphere and (b) Antarctica, from GLAC-1a (c) for the Northern Hemisphere, and from ANU for (d) the Northern Hemisphere and (e) Antarctica. The GLAC-1a reconstruction for Antarctica is identical to that of ICE-6Gv.2, and is therefore not shown. These reconstructed masks can be compared with the CMIP5/PMIP3 mask for (f) the Northern Hemisphere and (g) Antarctica. Cyan, blue and white areas indicate the groundedice, floating-ice and ice-free regions, respectively. 
reconstructions. In contrast, the region of western Antarctica characterised by large changes $(<900 \mathrm{~m})$ is more extensive in the CMIP5/PMIP3 composite reconstruction than in the earlier reconstructions, though this is partly due to the higher spatial resolution of the composite ice sheet compared to the earlier reconstructions.

\subsection{Magnitude of CMIP5/PMIP3 composite ice-sheet forcing}

The implied forcing resulting from the change in ice sheets and land-sea geography given by the CMIP5/PMIP3 composite is estimated using the Taylor et al. (2007) approximate partial-radiative perturbation method. The method is based on a simplified shortwave radiative model of the atmosphere. Surface absorption, atmospheric scattering and absorption are represented by means of three parameters that are diagnosed at each grid cell from surface and top-of-theatmosphere fluxes and albedo. These parameters are different in each model and simulation, and reflect the properties of the radiative code in the individual models and the differences of these terms in the different time periods. To quantify the effect of the change of each of these parameters, the parameters in the simple model are perturbed individually by the amount that they change in the climate response in order to compute the corresponding radiative change. We adopted a two-sided approach, in which two estimates of the radiative change are made considering the control simulation and the palaeosimulation in turn as a reference. According to these calculations, the forcing resulting from the change in the ice sheet alone is between -1.85 and $-3.49 \mathrm{~W} \mathrm{~m}^{-2}$, depending on the climate model (Table 3), while the total change in forcing resulting from the imposition of LGM boundary conditions varies between -3.62 and $-5.20 \mathrm{Wm}^{-2}$. The difference in forcing in simulations using the CMIP/PMIP composite (Fig. 6) and the PMIP2 ice sheet is ca. $1.0 \mathrm{Wm}^{-2}$. Technically, the estimated difference in forcing between the PMIP2 and CMIP5/PMIP3 simulations obtained through these analyses reflects both differences in the ice-sheet reconstruction (other boundary conditions are the same in the two sets of experiments) and differences in the version of the model used for the PMIP2 and CMIP5/PMIP3 experiments. Only three modelling groups (CCSM, IPSL, MIROC) have made LGM simulations in using both the PMIP2 and CMIP5/PMIP3 ice sheets. They show an average change in total forcing of $1.34 \mathrm{~W} \mathrm{~m}^{-2}$, with the change in radiative forcing caused by the ice sheet being ca. $1 \mathrm{~W} \mathrm{~m}^{-2}$, i.e. of comparable magnitude to the estimate obtained from the ensemble mean. The impact of changes in individual model configuration would be unlikely to yield the systematic increase in forcing between PMIP2 and CMIP5/PMIP3 shown by these three models. Thus, it seems plausible that the estimate of the effect of using the CMIP5/PMIP3 ice sheet obtained by comparing the PMIP2 and CMIP5/PMIP3 ensemble of simulations is realistic.

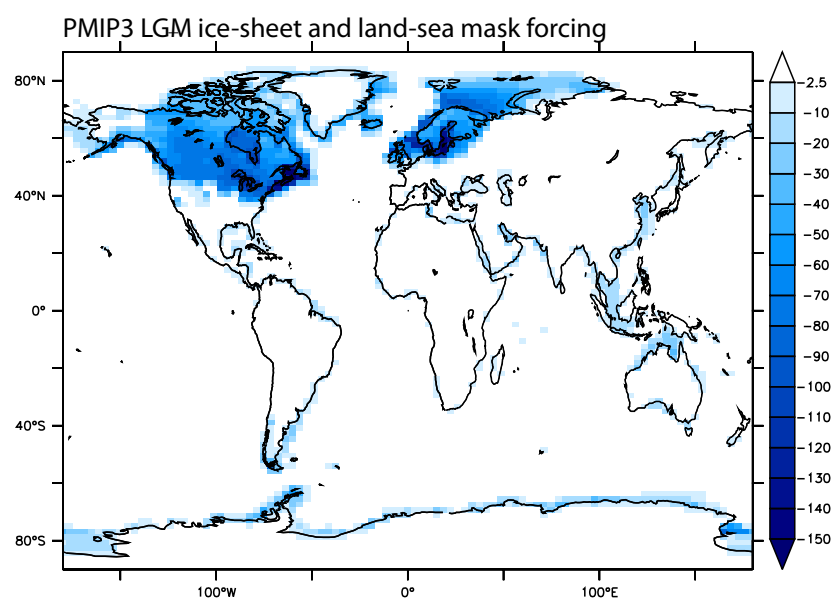

Figure 6. Estimation of the difference in radiative forcing $\left(\mathrm{W} \mathrm{m}^{-2}\right)$ at the LGM compared with pre-industrial conditions caused by imposition of the CMIP5/PMIP3 ice sheet and the change in the landsea mask. The map is a composite of the results from five oceanatmosphere models showing the spatial patterns of the change in total forcing associated with the expanded Northern Hemisphere ice sheets at the LGM and with the increase in land area due to a lowered sea level.

\subsection{Impact of differences between the ice-sheet reconstructions on climate}

To evaluate the impact of elevation differences between the individual ice sheets and the CMIP5/PMIP3 composite ice sheet on surface climate, we have run simulations with the atmosphere-slab ocean version of the MIROC3 model assuming no change in ocean heat transport from the control run and no change in the ocean mask. Using different ice-sheet reconstructions has an impact on surface temperature over the ice sheets themselves, and in adjacent regions of the ocean (Arctic, North Atlantic and Southern oceans), and a smaller impact over the Northern Hemisphere, partly through the influence on atmospheric stationary waves (Fig. 7). The largest differences from the CMIP5/PMIP composite occur where the reconstructions differ in terms of the ice extent (e.g. between North America and Greenland) or elevation (e.g. western Antarctica, Scandinavian ice sheet). The ANU reconstruction produces slightly colder temperatures in the Arctic than either ICE-6G v. 2 or GLAC-1a. The largest discrepancy occurs over Antarctica, where regional differences in temperature can be $>6{ }^{\circ} \mathrm{C}$ between the simulations using the ICE-6G v.2 and ANU reconstructions (Fig. 7).

According to the MIROC simulations (Fig. 7), the overall impact of using the CMIP5/PMIP3 composite ice sheet in preference to any individual reconstruction is smaller than the difference between the CMIP5/PMIP3 composite and the ICE-5G ice sheet used in the PMIP2 simulations. Comparison of the multi-model ensemble from PMIP2 and CMIP5/PMIP3 (Fig. 8) shows that the decision to move to a new generation of ice-sheet reconstructions has a large im- 
Table 3. Changes in radiative forcing $\left(\mathrm{W} \mathrm{m}^{-2}\right)$ associated with changes in the ice sheet and implied changes in land-sea geography, calculated for the CMIP5/PMIP3 composite and the PMIP2 ice sheets respectively. The resulting change in global annual mean surface air temperature $\left({ }^{\circ} \mathrm{C}\right)$ is shown in the last column. The error is calculated as the difference between the estimates obtained while using the present-day climate as a reference or the glacial climate as a reference in the partial-radiative perturbation calculation. Note that the values given for the PMIP2 ice sheet are slightly different from those given in Braconnot et al. (2012) because of corrections made subsequent to the publication of that paper. Values given here may also differ slightly from published results of individual models where either a different method or a different time window was used for the calculation.

\begin{tabular}{llcccc}
\hline Climate model & Ice sheet & $\begin{array}{c}\text { Ice-sheet change } \\
\left(\mathrm{W} \mathrm{m}^{-2}\right)\end{array}$ & $\begin{array}{c}\text { Land-sea change } \\
\left(\mathrm{W} \mathrm{m}^{-2}\right)\end{array}$ & $\begin{array}{c}\text { Combined change } \\
\left(\mathrm{W} \mathrm{m}^{-2}\right)\end{array}$ & $\begin{array}{c}\text { Temperature change } \\
\left({ }^{\circ} \mathrm{C}\right)\end{array}$ \\
\hline CCSM4 & CMIP5/PMIP3 & $-2.47 \pm 0.10$ & $-1.33 \pm 0.00$ & $-3.79 \pm 0.10$ & -4.91 \\
IPSL-CM5A-LR & CMIP5/PMIP3 & $-3.11 \pm 0.15$ & $-1.79 \pm 0.05$ & $-4.90 \pm 0.20$ & -4.60 \\
MIROC-ESM & CMIP5/PMIP3 & $-3.45 \pm 0.51$ & $-1.75 \pm 0.19$ & $-5.20 \pm 0.70$ & -5.00 \\
MPI-ESM-P & CMIP5/PMIP3 & $-3.49 \pm 0.62$ & $-1.08 \pm 0.06$ & $-4.57 \pm 0.68$ & -4.41 \\
MRI-CGCM3 & CMIP5/PMIP3 & $-1.85 \pm 0.10$ & $-1.77 \pm 0.02$ & $-3.62 \pm 0.12$ & -4.68 \\
CCSM3 & PMIP2 & $-1.85 \pm 0.12$ & $-0.88 \pm 0.00$ & $-2.72 \pm 0.12$ & -4.51 \\
CNRM & PMIP2 & $-2.25 \pm 0.32$ & $-0.74 \pm 0.01$ & $-2.98 \pm 0.32$ & -3.05 \\
HadCM3M2_oa & PMIP2 & $-2.55 \pm 0.40$ & $-1.19 \pm 0.11$ & $-3.73 \pm 0.51$ & -5.11 \\
HadCM3M2_oavM3M2_oa & PMIP2 & $-2.72 \pm 0.45$ & $-1.27 \pm 0.12$ & $-3.98 \pm 0.57$ & -5.86 \\
IPSL-CM4 & PMIP2 & $-2.43 \pm 0.11$ & $-1.17 \pm 0.03$ & $-3.60 \pm 0.13$ & -3.79 \\
MIROC3.2 & PMIP2 & $-2.76 \pm 0.54$ & $-0.78 \pm 0.12$ & $-3.54 \pm 0.66$ & -3.70 \\
\hline
\end{tabular}

pact on simulated LGM climate, not only in regions adjacent to the ice sheets, but also over the ocean and in the tropics. Based on these ensemble results, the use of the CMIP5/PMIP3 composite ice sheet together with the development of climate models produces an additional reduction of ca. $0.5^{\circ} \mathrm{C}$ in global mean annual temperature compared to the PMIP2 experiments.

\section{Discussion and conclusions}

There is currently no consensus about the form of the LGM ice sheets. Differences between existing reconstructions reflect the fact that new information is still emerging about the details of ice-sheet margins at the LGM and their retreat history, and the lithologic and geomorphic parameters that are used as constraints for ice-sheet modelling. While it is useful to explore the consequences of differences between reconstructions through sensitivity experiments, the use of a unified data set facilitates model-model intercomparison focusing on the role of structural differences between models. This was the motivation for the construction of a composite set of ice-sheet-related boundary conditions for the CMIP5/PMIP3 LGM experiment. It is heartening that the differences between the individual reconstructions contributing to the composite are relatively small and have only a minor impact on simulated $\mathrm{NH}$ radiative forcing and temperature.

The differences between the CMIP5/PMIP3 composite ice sheet and the ice sheets used in LGM simulations made during earlier phases of PMIP are not negligible. Braconnot et al. (2012) estimated that the difference between the prescribed land-sea mask from the PMIP2 and CMIP5/PMIP3 ice sheets would result in an additional $0.6 \mathrm{~W} \mathrm{~m}^{-2}$ forcing in the CMIP5/PMIP3 simulations, while the difference in icesheet height would result in temperatures ca. $0.6^{\circ} \mathrm{C}$ warmer than in the PMIP2 experiments. We estimate that, in fact, the difference in forcing in simulations using the CMIP/PMIP composite and the PMIP2 ice sheet is ca. $1.0 \mathrm{~W} \mathrm{~m}^{-2}$, and the average (ensemble) difference in the global mean annual temperature anomaly is ca. $0.5^{\circ} \mathrm{C}$. These estimates are derived from the ensemble of simulations made for each set of experiments, and thus we cannot exclude a contribution from changes in model configuration to the apparent difference in forcing and temperature response between the PMIP2 and CMIP5/PMIP3 results. However, the three models from the ensemble which performed both sets of experiments all show an estimate of a difference in forcing due to an icesheet configuration of ca. $1.0 \mathrm{~W} \mathrm{~m}^{-2}$, which suggests that this is a result of a systematic difference in the simulation protocol rather than the non-systematic changes that might be expected to result from changes in model configuration. While it would clearly be useful for a larger number of modelling groups to test the impact of an ice-sheet configuration, it seems plausible that the use of the CMIP5/PMIP3 ice sheet results in an increase in radiative forcing of ca. $1.0 \mathrm{~W} \mathrm{~m}^{-2}$ compared to the previous generation of PMIP simulations. The climate difference is non-negligible over the North Atlantic and over the continents of the Northern Hemisphere due to both radiative forcing and the atmospheric circulation change in multi-models, as well as the MIROC model sensitivity test.

Sensitivity experiments using the MIROC model show that the decision to use a composite ice sheet, rather than any of the existing ice-sheet realisations, does have an impact on simulated climate. The differences, however, are largely con- 
(a) PMIP2 - PMIP3 (MIROCs)

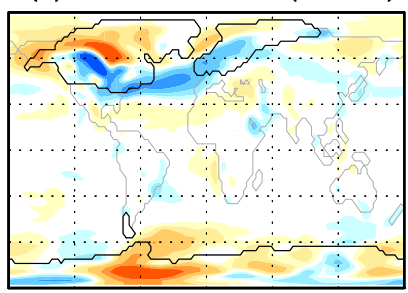

(c) GLAC1a - PMIP3
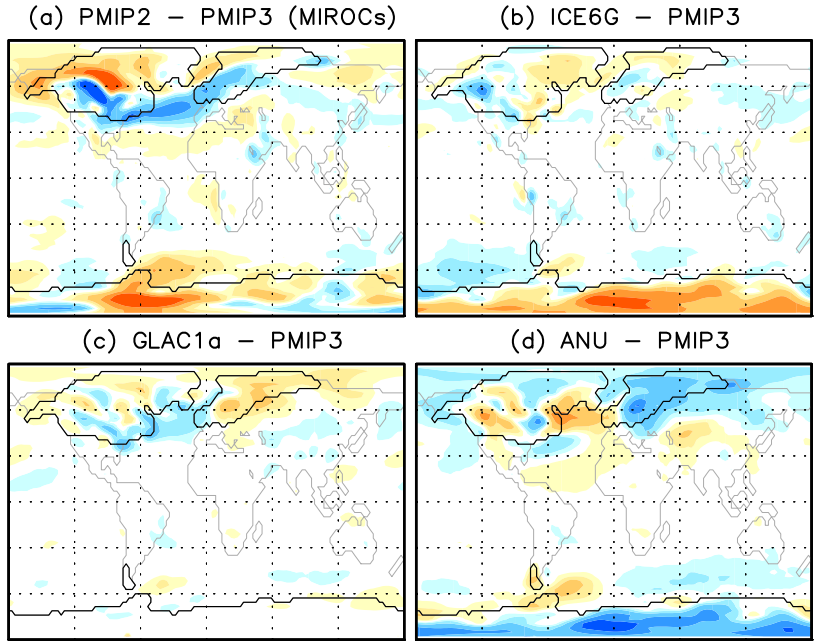

(d) ANU - PMIP3

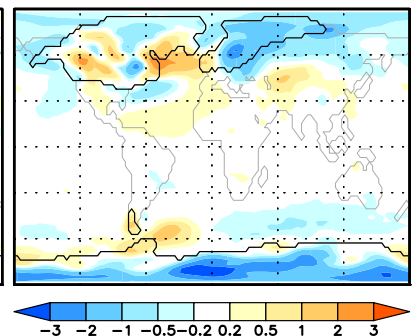

Figure 7. Differences in mean annual temperature $\left({ }^{\circ} \mathrm{C}\right)$ caused by using different ice-sheet configurations from the CMIP5/PMIP3 composite ice sheet in simulations made with the MIROC slab ocean model. The individual ice-sheet configurations are the (a) PMIP2, (b) ICE-6G v.2, (c) GLAC-1a, and (d) ANU ice sheets, where each is referenced to the CMIP5/PMIP3 composite ice sheet. The land mask ( $>50 \%$ land) is shown in grey; the ice margin ( $>50 \%$ ice) is shown in black in all four plots.

fined to the ice sheets themselves and adjacent oceans, and basically reflect disagreements between the independent reconstructions about ice extent and/or elevation. The choice makes little difference to simulated temperatures beyond the ice-sheet margins. Nevertheless, over the ice sheets, the differences in surface temperature can be large $\left(>5^{\circ} \mathrm{C}\right)$, and this could have a non-negligible impact on other aspects of the surface climate (see e.g. Chavaillaz et al., 2013) and ocean circulation. Testing the response of a fully coupled atmosphere-ocean model to these three reconstructions is beyond the scope of the present paper, but we would anticipate larger changes than in the atmosphere-slab ocean experiments, notably through the impact of the different reconstructions on westerly winds over the North Atlantic, which can, in turn, have an impact on the Atlantic Meridional Overturning Circulation (Ullman et al., 2014; Zhang et al., 2014). Thus, it is important that the differences between the reconstructions are examined carefully so that better-constrained reconstructions are available for future PMIP analyses. However, simulations made with the composite CMIP5/PMIP3 ice sheet have more realistic temperatures over Antarctica, falling within or very close to the uncertainty range of estimates of the LGM cooling derived from ice core data than the majority of PMIP2 simulations (Masson-Delmotte et al., 2013). While this may reflect model improvements to some extent, it would be unlikely to occur if the ice-sheet configuration of CMIP5/PMIP3 were substantially wrong. (a) PMIP2

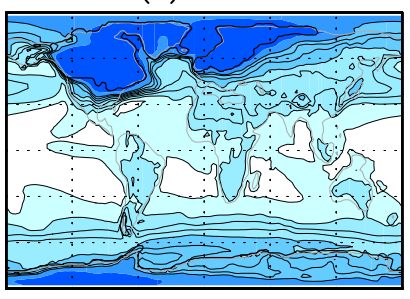

(c) PMIP2-PMIP3

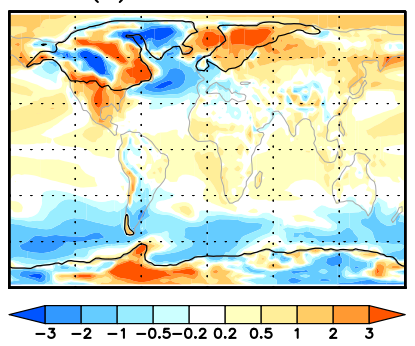

(b) PMIP3

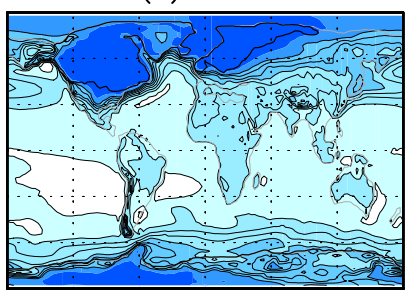

Figure 8. Change in mean annual temperature $\left({ }^{\circ} \mathrm{C}\right)$ in the (a) PMIP2 and (b) CMIP5/PMIP3 coupled ocean-atmosphere simulations. Each of these plots is an ensemble average of all the LGM simulations in PMIP2 and CMIP5/PMIP3 respectively. The difference between the ensemble mean results for the two generations of experiments is shown in plot (c). The land mask ( $>50 \%$ land) is shown in grey, and the ice margin ( $>50 \%$ ice) is shown in black in all plots. Contour lines in (a) and (b) are at $1{ }^{\circ} \mathrm{C}$ intervals to $-9{ }^{\circ} \mathrm{C}$; temperature differences $>-9^{\circ} \mathrm{C}$ are not differentiated.

There are differences between the actual, observed margin of each ice sheet at the LGM and the margins reconstructed by inverse modelling. Furthermore, the way in which ice-sheet topography and extent are implemented varies between different climate models. Thus, there may be differences between the CMIP5/PMIP3 ice-sheet mask and the mask used by an individual model (see e.g. Chavaillaz et al., 2013, Fig. 9). Both of these issues could be important in the processing of model outputs for model-model or datamodel comparison. This is clearly an issue that needs to be addressed more fully in the design of palaeo-simulations for the next phase of CMIP (CMIP6). Changes in palaeobathymetry, which is one output that can be obtained from the ice-sheet models (e.g. ICE-6G v.2), have rarely been implemented in a coupled ocean-atmosphere model context. The implications of palaeo-bathymetry changes for ocean circulation could be important, and again this is an issue that could be addressed in the future design of palaeoexperiments.

Our knowledge of the LGM ice-sheet/ice-shelf reconstruction is continually improving, as are the models that are used to reconstruct the most likely distribution of ice mass (Whitehouse et al., 2012; Anderson et al., 2014; Bentley et al., 2014; Mackintosh et al., 2014; Briggs et al., 2014; Lambeck et al., 2014; Peltier et al., 2015; Hall et al., 2015). Indeed, there have been updated reconstructions of the LGM ice-sheet configuration since the CMIP5/PMIP3 ice sheet was constructed. 


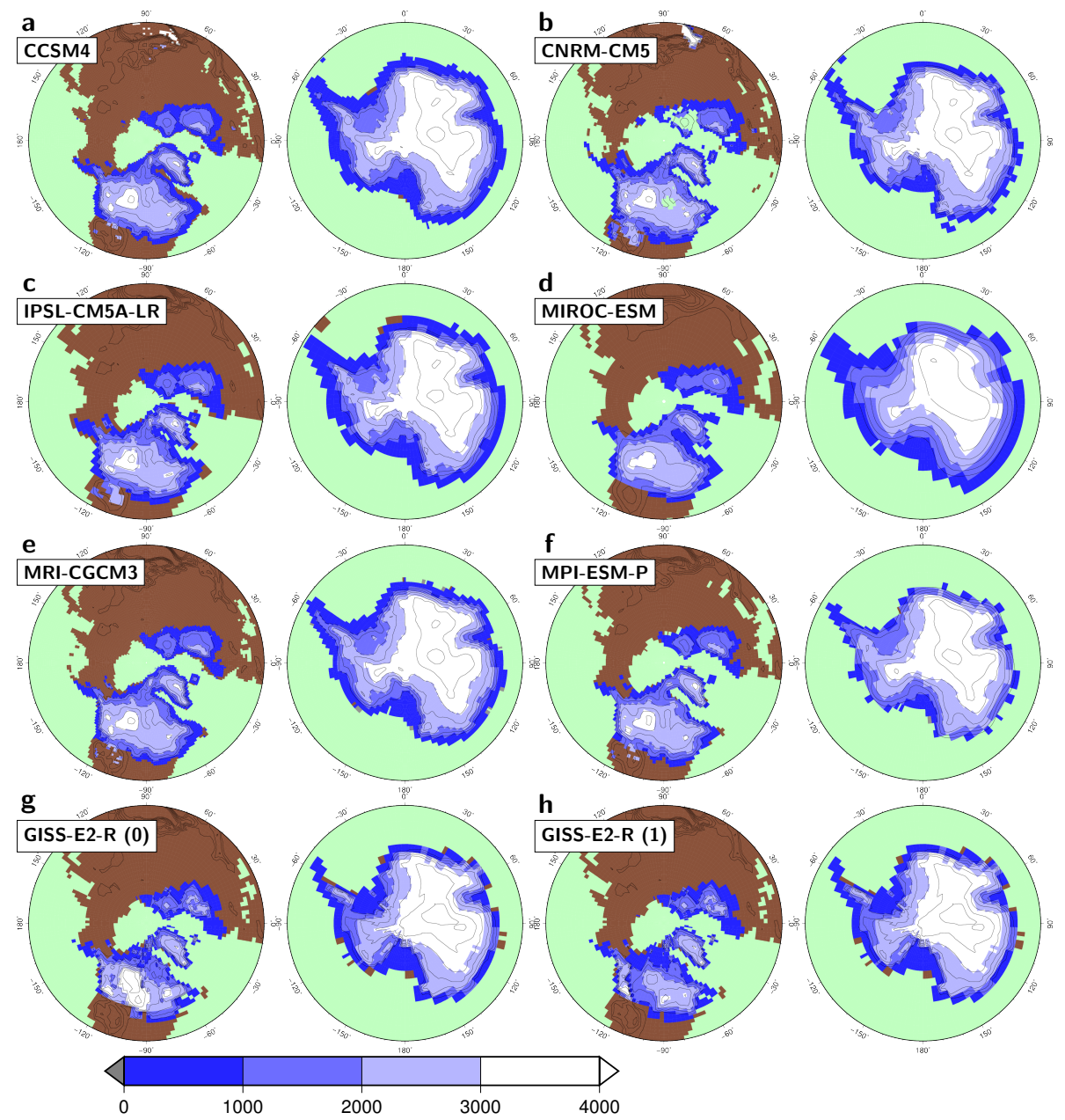

Figure 9. Implementation of the CMIP5/PMIP3 composite ice sheet in individual models. The plots show the surface elevation (m) as implemented in each model, and thus reveal that there are small differences in the prescribed ice sheet between models because of differences in e.g. model type and resolution.

For example, the ICE-6G_C (VM5a) reconstruction is an updated version of the ICE-6G (VM5a) v2.0 model discussed here, and is informed by a much richer database of space geodetic information (Argus et al., 2014; Peltier et al., 2015). It is inevitable that there will be further changes in the future, although less clear when there will be a consensus about their form. It is imperative, then, that a wider range of models conduct sensitivity tests of the impact of ice-sheet configurations, focusing on both near-field and remote impacts on climate. This would make it possible to draw on the wealth of palaeoclimate data from beyond the ice sheets to evaluate, and perhaps even constrain, ice-sheet reconstructions.

The Supplement related to this article is available online at doi:10.5194/gmd-8-3621-2015-supplement.
Acknowledgements. We thank Rosemarie Drummond and Rumi Ohgaito for technical assistance. We thank Catherine Ritz, Peter Clark, Anders Carlson, Jun'ichi Okuno, Heinz Blatter, all of those who contributed to the PMIP Wiki, and the participants in the PMIP and PALSEA workshops for scientific discussion. We acknowledge the World Climate Research Programme's Working Group on Coupled Modelling, which is responsible for CMIP, and we thank the climate modelling groups (listed in Table 3 of this paper) for producing and making available their model output. For CMIP the US Department of Energy's Program for Climate Model Diagnosis and Intercomparison provides coordinating support and led development of software infrastructure in partnership with the Global Organization for Earth System Science Portals. The numerical experiments by the MIROC model were carried out on the JAMSTEC Earth Simulator. The research was supported by JSPS KAKENHI grant 25241005. This paper is a contribution to the ongoing work on the Palaeoclimate Modelling Intercomparison Project.

Edited by: D. Roche 


\section{References}

Abe-Ouchi, A., Segawa, T., and Saito, F.: Climatic Conditions for modelling the Northern Hemisphere ice sheets throughout the ice age cycle, Clim. Past, 3, 423-438, doi:10.5194/cp-3-423-2007, 2007.

Abe-Ouchi, A., Saito, F., Kawamura, K., Raymo, M. E., Okuno, J., Takahashi, K., and Blatter, H.: Insolation-driven 100,000-year glacial cycles and hysteresis of ice-sheet volume, Nature, 500, 190-193, doi:10.1038/nature12374, 2013.

Alyea, F.: Numerical simulation of an ice age paleoclimate, Atmospheric Science Paper No. 193, Colorado State University, Fort Collins, Colorado, USA, 1972.

Amante, C. and Eakins, B.: ETOPO1 1 Arc-Minute Global Relief Model: Procedures, Data Sources and Analysis, NOAA Technical Memorandum NESDIS NGDC-24. National Geophysical Data Center, NOAA, Boulder, Colorado, USA, doi:10.7289/V5C8276M, 2009.

Anderson, J. B., Shipp, S. S., Lowe, A. L., Wellner, J. S., and Mosola, A. B.: The Antarctic Ice Sheet during the Last Glacial Maximum and its subsequent retreat history: a review, Quaternary Sci. Rev., 21, 49-70, 2002.

Anderson, J. B., Conway, H., Bart, P. J., Witus, A. E., Greenwood, S. L., McKay, R. M., Hall, B. L., Ackert, R. P., Licht, K., Jakobsson, M., and Stone, J. O.: Ross Sea paleo-ice sheet drainage and deglacial history during and since the $\{$ LGM $\}$, Quaternary Sci. Rev., 100, 31-54, doi:10.1016/j.quascirev.2013.08.020, 2014.

Argus, D. F. and Peltier, W. R.: Constraining models of postglacial rebound using space geodesy: a detailed assessment of model ICE-5G (VM2) and its relatives, Geophys. J. Int., 181, 697-723, doi:10.1111/j.1365-246X.2010.04562.x, 2010.

Argus, D. F., Peltier, W. R., Drummond, R., and Moore, A. W.: The Antarctica component of postglacial rebound model ICE-6G_C (VM5a) based on GPS positioning, exposure age dating of ice thicknesses, and relative sea level histories, Geophys. J. Int., 198, 537-563, doi:10.1093/gji/ggu140, 2014.

Bartlein, P. J., Harrison, S. P., Brewer, S., Connor, S., Davis, B. A. S., Gajewski, K., Guiot, J., Harrison-Prentice, T. I., Henderson, A., Peyron, O., Prentice, I. C., Scholze, M., Seppa, H., Shuman, B., Sugita, S., Thompson, R. S., Viau, A. E., Williams, J., and Wu, H.: Pollen-based continental climate reconstructions at 6 and $21 \mathrm{ka}$ a global synthesis, Clim. Dynam., 37, 775-802, doi:10.1007/s00382-010-0904-1, 2011.

Bentley, M. J., Cofaigh, C. Ó., Anderson, J. B., Conway, H., Davies, B., Graham, A. G., Hillenbrand, C.-D., Hodgson, D. A., Jamieson, S. S., Larter, R. D., Mackintosh, A., Smith, J. A., Verleyen, E., Ackert, R. P., Bart, P. J., Berg, S., Brunstein, D., Canals, M., Colhoun, E. A., Crosta, X., Dickens, W. A., Domack, E., Dowdeswell, J. A., Dunbar, R., Ehrmann, W., Evans, J., Favier, V., Fink, D., Fogwill, C. J., Glasser, N. F., Gohl, K., Golledge, N. R., Goodwin, I., Gore, D. B., Greenwood, S. L., Hall, B. L., Hall, K., Hedding, D. W., Hein, A. S., Hocking, E. P., Jakobsson, M., Johnson, J. S., Jomelli, V., Jones, R. S., Klages, J. P., Kristoffersen, Y., Kuhn, G., Leventer, A., Licht, K., Lilly, K., Lindow, J., Livingstone, S. J., Massé, G., McGlone, M. S., McKay, R. M., Melles, M., Miura, H., Mulvaney, R., Nel, W., Nitsche, F. O., O’Brien, P. E., Post, A. L., Roberts, S. J., Saunders, K. M., Selkirk, P. M., Simms, A. R., Spiegel, C., Stolldorf, T. D., Sugden, D. E., van der Putten, N., van Ommen, T., Verfaillie, D., Vyverman, W., Wagner, B., White,
D. A., Witus, A. E., and Zwartz, D.: A community-based geological reconstruction of Antarctic Ice Sheet deglaciation since the Last Glacial Maximum, Quaternary Sci. Rev., 100, 1-9, doi:10.1016/j.quascirev.2014.06.025, 2014.

Braconnot, P., Otto-Bliesner, B., Harrison, S., Joussaume, S., Peterchmitt, J.-Y., Abe-Ouchi, A., Crucifix, M., Driesschaert, E., Fichefet, Th., Hewitt, C. D., Kageyama, M., Kitoh, A., Laîné, A., Loutre, M.-F., Marti, O., Merkel, U., Ramstein, G., Valdes, P., Weber, S. L., Yu, Y., and Zhao, Y.: Results of PMIP2 coupled simulations of the Mid-Holocene and Last Glacial Maximum Part 1: experiments and large-scale features, Clim. Past, 3, 261277, doi:10.5194/cp-3-261-2007, 2007a.

Braconnot, P., Otto-Bliesner, B., Harrison, S., Joussaume, S., Peterchmitt, J.-Y., Abe-Ouchi, A., Crucifix, M., Driesschaert, E., Fichefet, Th., Hewitt, C. D., Kageyama, M., Kitoh, A., Loutre, M.-F., Marti, O., Merkel, U., Ramstein, G., Valdes, P., Weber, L., Yu, Y., and Zhao, Y.: Results of PMIP2 coupled simulations of the Mid-Holocene and Last Glacial Maximum - Part 2: feedbacks with emphasis on the location of the ITCZ and mid- and high latitudes heat budget, Clim. Past, 3, 279-296, doi:10.5194/cp-3-279-2007, 2007b.

Braconnot, P., Harrison, S. P., Kageyama, M., Bartlein, P. J., Masson-Delmotte, V., Abe-Ouchi, A., Otto-Bliesner, B., and Zhao, Y.: Evaluation of climate models using palaeoclimatic data, Nature Clim. Change, 2, 417-424, doi:10.1038/NCLIMATE1456, 2012.

Brady, E. C., Otto-Bliesner, B. L., Kay, J. E., and Rosenbloom, N.: Sensitivity to glacial forcing in the CCSM4, J. Climate, 26, 1901-1925, doi:10.1175/JCLI-D-11-00416.1, 2013.

Briggs, R. D., Pollard, D., and Tarasov, L.: A dataconstrained large ensemble analysis of Antarctic evolution since the Eemian, Quaternary Sci. Rev., 103, 91-115, doi:10.1016/j.quascirev.2014.09.003, 2014.

Broccoli, A. J.: Tropical Cooling at the Last Glacial Maximum: An Atmosphere-Mixed Layer Ocean Model Simulation, J. Climate, 13, 951-976, doi:10.1175/15200442(2000)013<0951:TCATLG>2.0.CO;2, 2000.

Broccoli, A. J. and Manabe, S.: The influence of continental ice, atmospheric $\mathrm{CO}_{2}$, and land albedo on the climate of the last glacial maximum, Clim. Dynam., 1, 87-99, doi:10.1007/BF01054478, 1987.

Brovkin, V., Ganopolski, A., Archer, D., and Munhoven, G.: Glacial $\mathrm{CO}_{2}$ cycle as a succession of key physical and biogeochemical processes, Clim. Past, 8, 251-264, doi:10.5194/cp-8-251-2012, 2012.

Chavaillaz, Y., Codron, F., and Kageyama, M.: Southern westerlies in LGM and future (RCP4.5) climates, Clim. Past, 9, 517-524, doi:10.5194/cp-9-517-2013, 2013.

Clark, P. U., Dyke, A. S., Shakun, J. D., Carlson, A. E., Clark, J., Wohlfarth, B., Mitrovica, J. X., Hostetler, S. W., and McCabe, A. M.: The Last Glacial Maximum, Science, 325, 710714, doi:10.1126/science.1172873, 2009.

CLIMAP: Seasonal reconstructions of the Earth's surface at the last glacial maximum, no. MC-36 in Map Chart Series, Geological Society of America, Boulder, Colorado, 1981.

CLIMAP Project Members: The Surface of the Earth, Science, 191, 1131-1137, 1976.

Collins, M., Knutti, R., Arblaster, J., Dufresne, J.-L., Fichefet, T., Friedlingstein, P., Gao, X., Gutowski, W., Johns, T., Krinner, 
G., Shongwe, M., Tebaldi, C., Weaver, A., and Wehner, M.: Long-term climate change: projections, commitments and irreversibility, in: Climate Change 2013: The Physical Science Basis. Contribution of Working Group I to the Fifth Assessment Report of the Intergovernmental Panel on Climate Change, edited by: Stocker, T., Qin, D., Plattner, G.-K., Tignor, M., Allen, S., Boschung, J., Nauels, A., Xia, Y., Bex, V., and Midgley, P., Cambridge University Press, Cambridge, United Kingdom and New York, NY, USA, 2013.

Dyke, A. S.: An outline of North American deglaciation with emphasis on central and northern Canada, in: Quaternary Glaciation - Extent and Chronology, Part II, edited by: Ehlers, J. and Gibbard, P. L., Vol. 26 of Developments in Quaternary Science, 374-424, Elsevier, Amsterdam, the Netherlands, 2004.

Dyke, A. S. and Prest, V. K.: Late Wisconsinan and Holocene history of the Laurentide ice sheet, Geogr. Phys. Quatern., 41, 237263, doi:10.7202/032681ar, 1987.

Ehlers, J., Gibbard, P. L., and Hughes, P. D.: Quaternary glaciationsextent and chronology: a closer look, Vol. 15, Elsevier, Amsterdam, the Netherlands, 2011.

Engelhart, S. E., Peltier, W. R., and Horton, B. P.: Holocene relative sea-level changes and glacial isostatic adjustment of the U.S. Atlantic coast, Geology, 39, 751-754, 2011.

Fleming, K. and Lambeck, K.: Constraints on the Greenland Ice Sheet since the Last Glacial Maximum from sea-level observations and glacial-rebound models, Quaternary Sci. Rev., 23, 1053-1077, doi:10.1016/j.quascirev.2003.11.001, 2004.

Ganopolski, A. and Calov, R.: The role of orbital forcing, carbon dioxide and regolith in $100 \mathrm{kyr}$ glacial cycles, Clim. Past, 7, 1415-1425, doi:10.5194/cp-7-1415-2011, 2011.

Gates, W. L.: Modeling the Ice-Age Climate, Science, 191, 11381144, doi:10.1126/science.191.4232.1138, 1976.

Gyllencreutz, G., Mangerud, J., Svendsen, J.-I., and Lohne, Ø.: DATED - a GIS-based reconstruction and dating database of the Eurasian deglaciation, in: Applied Quaternary Research in the Central Part of Glaciated Terrain, edited by: Johansson, P. and Sarala, P., 113-120, Geological Survey of Finland, Espoo, Finland, 2007.

Hall, B. L., Denton, G. H., Heath, S. L., Jackson, M. S., and Koffman, T. N. B.: Accumulation and marine forcing of ice dynamics in the western Ross Sea during the last deglaciation, Nat. Geosci., 8, 625-628, doi:10.1038/ngeo2478, 2015.

Hargreaves, J. C., Abe-Ouchi, A., and Annan, J. D.: Linking glacial and future climates through an ensemble of GCM simulations, Clim. Past, 3, 77-87, doi:10.5194/cp-3-77-2007, 2007.

Harrison, S. and Bartlein, P.: Records from the past, lessons for the future: what the palaeo-record implies about mechanisms of global change, in: The Future of the World's Climates, edited by: Henderson-Sellers, A. and McGuffie, K., 403-436, Elsevier, Amsterdam, the Netherlands, 2012.

Harrison, S. P., Bartlein, P. J., Izumi, K., Li, G., Annan, J., Hargreaves, J., Braconnot, P., and Kageyama, M.: Evaluation of CMIP5 palaeo-simulations to improve climate projections, Nature Clim. Change, 5, 735-743, doi:10.1038/nclimate2649, 2015

Hewitt, C. D. and Mitchell, J. F. B.: Radiative forcing and response of a GCM to ice age boundary conditions: cloud feedback and climate sensitivity, Clim. Dynam., 13, 821-834, doi:10.1007/s003820050199, 1997.
Hughes, A., Mangerud, J., Gyllencreutz, R., Svendsen, J., and Lohne, O.: Evolution of the Eurasian Ice Sheets during the last deglaciation (25-10 kyr), Abstract, American Geophysical Union Fall Meeting, San Francisco, 13-19 December 2014, 2014.

Justino, F., Timmermann, A., Merkel, U., and Souza, E. P.: Synoptic Reorganization of Atmospheric Flow during the Last Glacial Maximum, J. Climate, 18, 2826-2846, doi:10.1175/JCLI3403.1, 2005.

Kim, S. J.: The effect of atmospheric $\mathrm{CO}_{2}$ and ice sheet topography on LGM climate, Clim. Dynam., 22, 639-651, doi:10.1007/s00382-004-0412-2, 2004.

Kirtman, B., Power, S. B., Adedoyin, A. J., Boer, G. J., Bojariu, R., Camilloni, I., Doblas-Reyes, F., Fiore, A. M., Kimoto, M., Meehl, G., Prather, M., Sarr, A., Schär, C., Sutton, R., van Oldenborgh, G. J., Vecchi, G., and Wang, H.-J.: Near-term Climate Change: Projections and Predictability, in: Climate Change 2013: The Physical Science Basis. Contribution of Working Group I to the Fifth Assessment Report of the Intergovernmental Panel on Climate Change, edited by: Stocker, T., Qin, D., Plattner, G.-K., Tignor, M., Allen, S., Boschung, J., Nauels, A., Xia, Y., Bex, V., and Midgley, P., Cambridge University Press, Cambridge, United Kingdom and New York, NY, USA, 2013.

Kutzbach, J. E. and Guetter, P. J.: The Influence of Changing Orbital Parameters and Surface Boundary Conditions on Climate Simulations for the Past 18000 Years, J. Atmos. Sci., 43, 1726-1759, doi:10.1175/1520-0469(1986)043<1726:TIOCOP>2.0.CO;2, 1986.

Lambeck, K.: Glacial rebound of the British Isles - II. A highresolution, high-precision model, Geophys. J. Int., 115, 960-990, doi:10.1111/j.1365-246X.1993.tb01504.x, 1993.

Lambeck, K.: Late Pleistocene and Holocene sea-level change in Greece and south-western Turkey: a separation of eustatic, isostatic and tectonic contributions, Geophys. J. Int., 122, 10221044, doi:10.1111/j.1365-246X.1995.tb06853.x, 1995a.

Lambeck, K.: Late Devensian and Holocene shorelines of the British-Isles and North-Sea from models of glacio-hydroisostatic rebound, J. Geol. Soc., 152, 437-448, 1995b.

Lambeck, K.: Limits on the areal extent of the Barents Sea ice sheet in Late Weichselian time, Global Planet. Change, 12, 4151, doi:10.1016/0921-8181(95)00011-9, 1996.

Lambeck, K. and Chappell, J.: Sea Level Change Through the Last Glacial Cycle, Science, 292, 679-686, doi:10.1126/science.1059549, 2001.

Lambeck, K. and Johnston, P.: The viscosity of the mantle: evidence from analyses of glacial rebound phenomena, in: The Earth's Mantle, edited by: Jackson, I., 461-502, Cambridge Univ. Press, Cambridge, 1998.

Lambeck, K. and Purcell, A.: Sea-level change in the Mediterranean Sea since the LGM: model predictions for tectonically stable areas, Quaternary Sci. Rev., 24, 1969-1988, doi:10.1016/j.quascirev.2004.06.025, 2005.

Lambeck, K., Smither, C., and Johnston, P.: Sea-level change, glacial rebound and mantle viscosity fornorthern $\mathrm{Eu}-$ rope, Geophys. J. Int., 134, 102-144, doi:10.1046/j.1365246x.1998.00541.x, 1998.

Lambeck, K., Yokoyama, Y., and Purcell, T.: Into and out of the Last Glacial Maximum: sea-level change during Oxygen 
Isotope Stages 3 and 2, Quaternary Sci. Rev., 21, 343-360, doi:10.1016/S0277-3791(01)00071-3, 2002.

Lambeck, K., Purcell, A., Johnston, P., Nakada, M., and Yokoyama, Y.: Water-load definition in the glacio-hydroisostatic sea-level equation, Quaternary Sci. Rev., 22, 309-318, doi:10.1016/S0277-3791(02)00142-7, 2003.

Lambeck, K., Purcell, A., Zhao, J., and Svensson, N.-O.: The Scandinavian Ice Sheet: from MIS 4 to the end of the Last Glacial Maximum, Boreas, 39, 410-435, doi:10.1111/j.15023885.2010.00140.x, 2010.

Lambeck, K., Rouby, H., Purcell, A., Sun, Y., and Sambridge, M.: Sea level and global ice volumes from the Last Glacial Maximum to the Holocene, P. Natl. Acad. Sci. USA, 111, 15296-15303, doi:10.1073/pnas.1411762111, 2014.

Mackintosh, A. N., Verleyen, E., O'Brien, P. E., White, D. A., Jones, R. S., McKay, R., Dunbar, R., Gore, D. B., Fink, D., Post, A. L., Miura, H., Leventer, A., Goodwin, I., Hodgson, D. A., Lilly, K., Crosta, X., Golledge, N. R., Wagner, B., Berg, S., van Ommen, T., Zwartz, D., Roberts, S. J., Vyverman, W., and Masse, G.: Retreat history of the East Antarctic Ice Sheet since the Last Glacial Maximum, Quaternary Sci. Rev., 100, 10-30, doi:10.1016/j.quascirev.2013.07.024, 2014.

Manabe, S. and Hahn, D. G.: Simulation of the tropical climate of an ice age, J. Geophys. Res., 82, 3889-3911, doi:10.1029/JC082i027p03889, 1977.

Mangerud, J., Astakhov, V. I., Murray, A., and Svendsen, J. I.: The chronology of a large ice-dammed lake and the Barents-Kara Ice Sheet advances, Northern Russia, Global Planet. Change, 31, 321-336, doi:10.1016/S0921-8181(01)00127-8, 2001.

Mangerud, J., Astakhov, V., and Svendsen, J.-I.: The extent of the Barents-Kara ice sheet during the Last Glacial Maximum, Quaternary Sci. Rev., 21, 111-119, doi:10.1016/S02773791(01)00088-9, 2002.

Mangerud, J., Goehring, B. M., Lohne, Ø. S., Svendsen, J. I., and Gyllencreutz, R.: Collapse of marine-based outlet glaciers from the Scandinavian Ice Sheet, Quaternary Sci. Rev., 67, 8-16, doi:10.1016/j.quascirev.2013.01.024, 2013.

MARGO Project Members: Constraints on the magnitude and patterns of ocean cooling at the Last Glacial Maximum, Nat. Geosci., 2, 127-132, doi:10.1038/ngeo411, 2009.

Masson-Delmotte, V., Kageyama, M., Braconnot, P., Charbit, S., Krinner, G., Ritz, C., Guilyardi, E., Jouzel, J., Abe-Ouchi, A., Crucifix, M., Gladstone, R., Hewitt, C., Kitoh, A., LeGrande, A., Marti, O., Merkel, U., Motoi, T., Ohgaito, R., Otto-Bliesner, B., Peltier, W., Ross, I., Valdes, P., Vettoretti, G., Weber, S., Wolk, F., and $\mathrm{Yu}, \mathrm{Y}$.: Past and future polar amplification of climate change: climate model intercomparisons and ice-core constraints, Clim. Dynam., 26, 513-529, doi:10.1007/s00382-005-0081-9, 2006.

Masson-Delmotte, V., Schulz, M., Abe-Ouchi, A., Beer, J., Ganopolski, J., González Rouco, J., Jansen, E., Lambeck, K., Luterbacher, J., Naish, T., Osborn, T., Otto-Bliesner, B., Quinn, T., Ramesh, R., Rojas, M., Shao, X., and Timmermann, A.: Information from paleoclimate archives, in: Climate Change 2013: The Physical Science Basis. Contribution of Working Group I to the Fifth Assessment Report of the Intergovernmental Panel on Climate Change, edited by: Stocker, T., Qin, D., Plattner, G.-K., Tignor, M., Allen, S., Boschung, J., Nauels, A., Xia, Y., Bex, V., and Midgley, P., Cambridge University Press, Cambridge, United Kingdom and New York, NY, USA, 2013.
Mickelson, D. and Colgan, P.: The southern Laurentide Ice Sheet in the United States: What have we learned in the last 40 years?, in: Glacial Landsystems, edited by: Evans, D. and Rea, B., 111-142, Erwin Arnold, London, 2003.

Nakada, M. and Lambeck, K.: Late Pleistocene and Holocene sealevel change in the Australian region and mantle rheology, Geophys. J., 96, 497-517, 1989.

Otto-Bliesner, B. L., Brady, E. C., Clauzet, G., Tomas, R., Levis, S., and Kothavala, Z.: Last Glacial Maximum and Holocene Climate in CCSM3, J. Climate, 19, 2526-2544, doi:10.1175/JCLI3748.1, 2006.

Paterson, W. S. B.: The Physics of Glaciers, Pergamon, Oxford, 3rd Edn., 1994.

Pausata, F. S. R., Li, C., Wettstein, J. J., Kageyama, M., and Nisancioglu, K. H.: The key role of topography in altering North Atlantic atmospheric circulation during the last glacial period, Clim. Past, 7, 1089-1101, doi:10.5194/cp-7-1089-2011, 2011.

Peltier, W. R.: The impulse response of a Maxwell Earth, Rev. Geophys. Space Phys., 12, 649-669, 1974.

Peltier, W. R.: Glacial isostatic adjustment II: the inverse problem, Geophys. J. R. Astr. Soc., 46, 669-706, 1976.

Peltier, W. R.: Ice Age Paleotopography, Science, 265, 195-201, 1994.

Peltier, W. R.: On eustatic sea level history: Last Glacial Maximum to Holocene, Quaternary Sci. Rev., 21, 377-396, 2002.

Peltier, W. R.: Global Glacial Isostasy and the Surface of the IceAge Earth: The ICE-5G(VM2) Model and GRACE, Annu. Rev. Earth Planet. Sc., 32, 111-149, 2004.

Peltier, W. R.: Closure of the budget of global sea level rise over the GRACE era: the importance and magnitudes of the required corrections for global glacial isostatic adjustment, Quaternary Sci. Rev., 28, 1658-1674, doi:10.1016/j.quascirev.2009.04.004, 2009.

Peltier, W. R. and Andrews, J. T.: Glacial isostatic adjustment I: the forward problem, Geophys. J. R. Astr. Soc., 46, 605-646, 1976.

Peltier, W. R. and Drummond, R.: Rheological stratification of the lithosphere: A direct inference based upon the geodetically observed pattern of the glacial isostatic adjustment of the North American continent, Geophys. Res. Lett., 35, L16314, doi:10.1029/2008GL034586, 2008.

Peltier, W. R., Argus, D. F., and Drummond, R.: Space geodesy constrains ice age terminal deglaciation: The global ICE-6G_C (VM5a) model, J. Geophys. Res.-Sol. Ea., 120, 450-487, doi:10.1002/2014JB011176, 2015.

Prentice, I. C., Jolly, D., and BIOME 6000 participants: MidHolocene and glacial-maximum vegetation geography of the northern continents and Africa, J. Biogeogr., 27, 507-519, doi:10.1046/j.1365-2699.2000.00425.x, 2000.

Roy, K. and Peltier, W.: Glacial isostatic adjustment, relative sea level history and mantle viscosity: reconciling relative sea level model predictions for the U.S. East coast with geological constraints, Geophys. J. Int., 201, 1156-1181, doi:10.1093/gji/ggv066, 2015.

Schmidt, G. A., Annan, J. D., Bartlein, P. J., Cook, B. I., Guilyardi, E., Hargreaves, J. C., Harrison, S. P., Kageyama, M., LeGrande, A. N., Konecky, B., Lovejoy, S., Mann, M. E., Masson-Delmotte, V., Risi, C., Thompson, D., Timmermann, A., Tremblay, L.B., and Yiou, P.: Using palaeo-climate comparisons to con- 
strain future projections in CMIP5, Clim. Past, 10, 221-250, doi:10.5194/cp-10-221-2014, 2014.

Schmittner, A., Urban, N. M., Shakun, J. D., Mahowald, N. M., Clark, P. U., Bartlein, P. J., Mix, A. C., and Rosell-Melé, A.: Climate Sensitivity Estimated from Temperature Reconstructions of the Last Glacial Maximum, Science, 334, 1385-1388, doi:10.1126/science.1203513, 2011.

Shennan, I., Peltier, W., Drummond, R., and Horton, B.: Global to local scale parameters determining relative sea-level changes and the post-glacial isostatic adjustment of Great Britain, Quaternary Sci. Rev., 21, 397-408, doi:10.1016/S0277-3791(01)000919, 2002.

Simpson, M. J. R., Milne, G. A., Huybrechts, P., and Long, A. J.: Calibrating a glaciological model of the Greenland ice sheet from the Last Glacial Maximum to present-day using field observations of relative sea level and ice extent, Quaternary Sci. Rev., 28, 1631-1657, doi:10.1016/j.quascirev.2009.03.004, 2009.

Svendsen, J. I., Astakhov, V. I., Bolshiyanov, D. Y., Demidov, I., Dowdeswell, J. A., Gataullin, V., Hjort, C., Hubberten, H. W., Larsen, E., Mangerud, J., Melles, M., Möller, P., Saarnisto, M., and Siegert, M. J.: Maximum extent of the Eurasian ice sheets in the Barents and Kara Sea region during the Weichselian, Boreas, 28, 234-242, doi:10.1111/j.1502-3885.1999.tb00217.x, 1999.

Svendsen, J. I., Gataullin, V., Mangerud, J., and Polyak, L.: The glacial History of the Barents and Kara Sea Region, in: Quaternary Glaciations Extent and Chronology Part I: Europe, edited by: Ehlers, J. and Gibbard, P., Vol. 2, Part 1 of Developments in Quaternary Sciences, 369-378, Elsevier, Amsterdam, the Netherlands, doi:10.1016/S1571-0866(04)80086-1, 2004.

Tarasov, L. and Peltier, W. R.: Greenland glacial history and local geodynamic consequences, Geophys. J. Int., 150, 198-229, doi:10.1046/j.1365-246X.2002.01702.x, 2002.

Tarasov, L. and Peltier, W. R.: Greenland glacial history, borehole constraints, and Eemian extent, J. Geophys. Res., 108, 2143, doi:10.1029/2001JB001731, 2003.

Tarasov, L. and Peltier, W. R.: A geophysically constrained large ensemble analysis of the deglacial history of the North American ice-sheet complex, Quaternary Sci. Rev., 23, 359-388, doi:10.1016/j.quascirev.2003.08.004, 2004.

Tarasov, L. and Peltier, W. R.: Arctic freshwater forcing of the Younger Dryas cold reversal, Nature, 435, 662-665, doi:10.1038/nature03617, 2005.

Tarasov, L. and Peltier, W. R.: Coevolution of continental ice cover and permafrost extent over the last glacial-interglacial cycle in North America, J. Geophys. Res., 112, F02S08, doi:10.1029/2006JF000661, 2007.

Tarasov, L., Dyke, A. S., Neal, R. M., and Peltier, W. R.: A data-calibrated distribution of deglacial chronologies for the North American ice complex from glaciological modeling, Earth Planet. Sc. Lett., 315-316, 30-40, doi:10.1016/j.eps1.2011.09.010, 2012.
Taylor, K. E., Crucifix, M., Braconnot, P., Hewitt, C. D., Doutriaux, C., Broccoli, A. J., Mitchell, J. F. B., and Webb, M. J.: Estimating Shortwave Radiative Forcing and Response in Climate Models, J. Climate, 20, 2530-2543, doi:10.1175/JCLI4143.1, 2007.

Taylor, K. E., Stouffer, R. J., and Meehl, G. A.: An Overview of CMIP5 and the Experiment Design, B. Am. Meteorol. Soc., 93, 485-498, doi:10.1175/BAMS-D-11-00094.1, 2012.

Toscano, M. A., Peltier, W. R., and Drummond, R.: ICE-5G and ICE-6G models of postglacial relative sea-level history applied to the Holocene coral reef record of northeastern St Croix, U.S.V.I.: investigating the influence of rotational feedback on GIA processes at tropical latitudes, Quaternary Sci. Rev., 30, 3032-3042, 2011.

Tushingham, A. M. and Peltier, W. R.: ICE-3G: A new global model of late Pleistocene deglaciation based upon geophysical predictions of post-glacial relative sea level change, J. Geophys. Res., 96, 4497-4523, 1991.

Ullman, D. J., LeGrande, A. N., Carlson, A. E., Anslow, F. S., and Licciardi, J. M.: Assessing the impact of Laurentide Ice Sheet topography on glacial climate, Clim. Past, 10, 487-507, doi:10.5194/cp-10-487-2014, 2014.

Vettoretti, G. and Peltier, W. R.: Last Glacial Maximum ice sheet impacts on North Atlantic climate variability: The importance of the sea ice lid, Geophys. Res. Lett., 40, 6378-6383, doi:10.1002/2013GL058486, 2013.

Whitehouse, P. L., Bentley, M. J., and Brocq, A. M. L.: A deglacial model for Antarctica: geological constraints and glaciological modelling as a basis for a new model of Antarctic glacial isostatic adjustment, Quaternary Sci. Rev., 32, 1-24, doi:10.1016/j.quascirev.2011.11.016, 2012.

Williams, J., Barry, R. G., and Washington, W. M.: Simulation of the Atmospheric Circulation Using the NCAR Global Circulation Model with Ice Age Boundary Conditions, J. Appl. Meteorol., 13, 305-317, doi:10.1175/15200450(1974)013<0305:SOTACU>2.0.CO;2, 1974.

Yoshimori, M., Yokohata, T., and Abe-Ouchi, A.: A Comparison of Climate Feedback Strength between $\mathrm{CO}_{2}$ Doubling and LGM Experiments, J. Climate, 22, 3374-3395, doi:10.1175/2009JCLI2801.1, 2009.

Yoshimori, M., Hargreaves, J. C., Annan, J. D., Yokohata, T., and Abe-Ouchi, A.: Dependency of Feedbacks on Forcing and Climate State in Physics Parameter Ensembles, J. Climate, 24, 6440-6455, doi:10.1175/2011JCLI3954.1, 2011.

Zhang, X., Lohmann, G., Knorr, G., and Purcell, C.: Abrupt glacial climate shifts controlled by ice sheet changes, Nature, 512, 290 294, doi:10.1038/nature13592, 2014 